\title{
Memlük Sultanı Berkuk Döneminde Mezâlim Davaları
}

\author{
M. Fatih Yalçın \\ Dr. Öğr. Üyesi, Bilecik Şeyh Edebali Üniversitesi (ROR ID: 00dzfx204) \\ İslami İlimler Fakültesi, İslam Tarihi Anabilim Dalı \\ Assistant Professor Dr., Bilecik Şeyh Edebali University, Faculty of Islamic Sciences \\ Department of Islamic History \\ Bilecik/Turkey \\ fatih.yalcin@bilecik.edu.tr \\ ORCID: 0000-0003-3685-2988
}

\begin{abstract}
The purpose of this article is to present the issues about which people applied to the mazālim court, the problems that occured between statesmen and people, and the sentences imposed by the court in the Barquq period. The fact that Mamluks, who inherited the Ayyubid state tradition, were advanced in historiography enables the study of mazālim court cases, even though we do not have the court records. The increase in records about mazālim courts especially during the reigns of relatively more powerful Mamluk sultans is noteworthy. One example of this is Sultan Barquq, who is regarded as the sultan who ended the Bahri Mamluk period and ushered in the Burji Mamluk period. Sultan Barquq, like his predecessors, had been very interested in the mazālim courts and instituted two important changes. The first of these was to change the building in which the court sessions were held. Barquq, who ascended to the throne in 784 (1382), presided over the court until 789 (1387) in the daruladl building that was used since the Muhammad b. Qalawun period, but later the court started convening in al-Istabl al-Sultani. Sources do not tell anything about why this change was made. However, there are commentaries about how this change put pressure on statesmen. This change in location made it easier for the people to bring their cases to the court. One can think that the sultan instituted this to keep statesmen under his control and to dominate them. However, one can only find one court case against a high ranking emir close to the palace and that one amir was acquitted after trial. Amirs who were tried in mazālim in this period were usually from districts outside of Cairo and lower ranking. However, the situation is different when it comes to the scholarly class. First, among the scholars against whom there was a mazālim court case, all but one had a position. A huge chunk were in positions of high religious and legal authority like Shafi'i Chief Justice of Damascus, Maliki Deputy Chief Justice of Cairo, Maliki Chief Justice of Alexandria, Chief Sheikh of Siryakus, and Chief Sheikh of Qawsoon, and so on. When one also considers the fact that these people lost their positions as a result of these trials, the idea that this change in location was a move against the scholarly class gains weight. However, another issue that comes to mind is that high ranking
\end{abstract}

Mazālim Court Cases During The Reign of Mamluk Sultan Barquq

İntihal Taramas1/Plagiarism Detection: Bu makale intihal taramasından geçirildi/This paper was checked for plagiarism Etik Beyan/Ethical Statement: Bu çalışmanın hazırlanma sürecinde bilimsel ve etik ilkelere uyulduğu ve yararlanılan tüm çalışmaların kaynakçada belirtildiği beyan olunur/It is declared that scientific and ethical principles have been followed while carrying out and writing this study and that all the sources used have been properly cited (M. Fatih Yalçın).

Geliş/Received: 14 Ekim/October 2020 | Kabul/Accepted: 24 Şubat/Fabruary 2021 | Yayın/Published: 20 Mart/March 2021

Atıf/Cite as: M. Fatih Yalçın, "Memlük Sultanı Berkuk Döneminde Mezâlim Davaları = Maẓālim Court Cases During The Reign Of Mamluk Sultan Barquq”, Eskiyeni 43 (Mart/March 2021), 289-314. https://doi.org/10.37697/eskiyeni.810734 CC BY-NC 4.0 | This paper is licensed under a Creative Commons Attribution-NonCommercial License 
amirs may have managed to improve their relations with the people, which may have made them less affected by the change. Also, the fact that cases against the scholarly class involved investigations as to whether they had been collaborating with the amirs makes one think that the military class was kept in check through this process.

The second adjustment that Barquq did to the mazālim courts was the change to the session days. During his sixteen year reign, Barquq changed the court days three times. Since its inception, the Mamluks traditionally held their mazaalim court sessions on Mondays and Thursdays. Barquq changed this to Sundays and Wednesdays. The exact date of this first change is not known. Later, from 797 (1395) onwards, the court began convening on Tuesdays and Saturdays. Historians say that the sultan did this change because he spared Sunday and Wednesdays to entertainment with the amirs. According to them, the sultan did this change to spend the day after the court day with entertainment with the amirs. However, this explanation does not seem very plausible.

The third change was to add sessions on Friday afternoon as a supplement to Tuesday and Saturday. This change coincides with the last year of the sultan's reign. The sultan probably increased the number of days of the mazālim courts in order to improve his relationship with the people. Of the twenty-two cases found in the Barquq period, ten were against scholars and nine against members of the military class. The remaining three were against converts of Christian origin. Sources rarely mention the names of the plaintiffs. Instead, generic expressions like, a group of farmers, a sufi group, a merchant, a woman, a Christian, and so on are used. This is important in showing that most plaintiffs were from among the ordinary people and the mazālim court of the Barquq period had a close relationship with the people.

\section{Keywords}

Islamic History, Mamluks, Barquq, Mazāalim, Cases

\section{Memlük Sultanı Berkuk Döneminde Mezâlim Davaları}

\section{Öz}

Bu makalenin amacı, Berkuk döneminde halkın hangi konulardaki şikâyetlerini mezâlim mahkemesine taşıdığı, devlet ricâlinin halkla yaşadığı sorunları ve dava sonuçlarında verilen cezaları ortaya koymaktır. Eyyûbîlerin devlet teşkilatı geleneğini tevarüs eden Memlüklerde tarihçiliğin oldukça gelişmiş olması, her ne kadar mahkeme kayıtları elimizde olmasa da mezâlim davalarıyla ilgili çalışma imkânı sunmaktadır. Özellikle güçlü Memlük sultanları dönemlerinde mezâlime dair kayıtlarda artış olduğu gözlerden kaçmamaktadır. Bunun önde gelen örneklerinden biri de Bahrî Memlükler dönemini sona erdirerek Burcî Memlükler dönemini başlattığı kabul edilen Sultan Berkuk dönemidir. Sultan Berkuk, selefleri gibi mezâlim oturumlarıyla yakından ilgilenmiş ve yaptığı iki düzenlemeyle de dikkat çekmiştir. Bu düzenlemelerden birincisi, mezâlim oturumlarının yapıldı̆̆ı binanın değiştirilmesidir. 784 (1382) yılında tahta çıkan Berkuk, 789 (1387) yılına kadar Muhammed b. Kalavun döneminden beri kullanılan dârüladl binasında mezâlim oturumlarına başkanlık yapmış, ancak daha sonra el-Istablü's-Sultânî'de söz konusu oturumlar tertip edilmeye başlanmıştır. Kaynaklar bu düzenlemenin neden yapıldığına dair bir bilgi aktarmamaktadır. Bununla birlikte yapılan düzenlemenin devlet ricâlini baskı altına aldığına dair değerlendirmelerde bulunmuşlardır. Mekânda yapılan bu değişim, halkın daha kolay bir şekilde şikâyetlerini mahkemeye ulaştırmasına vesile olmuştu. Bu durum göz önüne alındığında, söz konusu düzenlemeyle sultanın devlet ricâlini kontrol altında tutmak ve onlara tahakküm etmek arzusunda olduğu akla gelmektedir. Ancak özellikle saray çevresinde görevli üst düzey rütbeli emîrler hakkında sadece bir mezâlim davası tespit edilmiştir. $O$ da yargılama neticesinde beraat etmiştir. Bu dönemde mezâlimde yargılanan emîrler, çoğunlukla Kahire dışındaki bölgelerde görevli ve düşük rütbeliydi. Bununla birlikte ilmiye sınıfında 
durum biraz farklıdır. Öncelikle, hakkında mezâlim davası açılan ilmiye sınıfı mensuplarının biri hariç hepsinin bir görevi mevcuttu. Bunların önemli kısmının da Dımaşk şâfiî kâdılkudâtlığı, Kahire Mâlikî kâdılkudât nâibliği, İskenderiye Mâlikî kâdılkudâtlığı, Siryakus hankahı şeyhüşşuyûhluğu ve Kavsun hankahı şeyhüşşuyûhluğu gibi adlî veya dinî üst düzey bir göreve sahip olduğu görülmektedir. Yargılama sonucu onların görevlerinden azledildiği de göz önüne alındığında, mezâlim oturumlarının halka daha açık hale getiren mekân değişikliğinin ilmiye sınıfına yönelik bir hamle olduğuna dair bir kanaat ortaya çıkmaktadır. Ancak burada akla gelen bir diğer husus, üst düzey ümerâ sınıfının halkla arasında iyi ilişkiler geliştirmeyi başararak mezâlim oturumlarının mekânına dair yapılan değişiklikten daha az etkilenmesidir. Yine ilmiye sınıfı aleyhine açılan davalarda ümerâyla iş birliğinin olup olmadığının da araştırılması, askerî sınıfın bu şekilde kontrol altında tutulduğunu düşündürmektedir. Berkuk'un mezâlim oturumlarına dair ikinci düzenlemesi oturum günlerinin değiștirilmesi olmuştur. Berkuk, on altı yıllık iktidarı boyunca oturumların günlerini üç kez değiştirmiştir. Kuruluşundan itibaren Memlüklerde mezâlim oturumlarının pazartesi ve perşembe günleri toplanması âdetti. Berkuk bunu pazar ve çarşamba günleri olarak değiştirmiştir. Bu ilk değişikliğin kesin tarihi bilinmemektedir. Daha sonra 797 (1395) yılından itibaren salı ve cumartesi günleri mahkeme toplanmışır. Tarihçiler, Sultanın pazar ve çarşamba günlerini emîrlerle eğlenceye ayırması dolayısıyla böyle bir değişikliğe gittiğini belirtmektedirler. Yani onlara göre, mezâlim oturumlarından bir gün sonra Sultan, emîrlerle eğlenmek için bu şekilde bir tasarrufta bulunmuştur. Ancak bu izahât, yeterince mantıklı görünmemektedir. Üçüncü değişiklik ise salı ve cumartesi günlerine ilave yapılmak suretiyle cuma günü öğleden sonra oturumların düzenlemesi şeklindedir. Bu değişiklik sultanın iktidarının son yılına rastlamaktadır. Muhtemelen Sultan, halkla olan ilişkisini daha da artırmak amacıyla mezâlim oturumlarını üç güne çıkarmış olmalıdır. Berkuk döneminde tespit edilen yirmi iki davanın onu ilmiye, dokuzu askerî sınıf mensupları aleyhinedir. Geriye kalan üç dava da Hıristiyan asıllı mühtediler aleyhinedir. Kaynaklarda müştekilerin ismi nadiren zikredilmektedir. Bunun yerine, bir grup çiftçi, sufi bir grup, bir tâcir, bir kadın ve bir Hıristiyan gibi genel ifadeler kullanılmaktadır. Bu durum, müştekilerin çoğunluğunun halk tabakasından olduğunu ve Berkuk döneminde mezâlim mahkemesinin halkla olan yakın iletişimi göstermesi bakımından önemlidir.

\section{Anahtar Kelimeler}

İslam Tarihi, Memlükler, Berkuk, Mezâlim, Davalar

\section{Giriş}

İki kez tahta oturan Berkuk (784-791/1382-1389 ve 792-801/1390-1399), Çerkez asıllı bir memlüktür. Çerkez olarak adlandırılan memlükler, Sultan Kalavun döneminde (678689/1279-1290) satın alınarak Kahire'ye ilk defa getirilmeye başlanmıştır. Kısa zamanda sayıları artarak güçlenmişler ve aralarından Baybars el-Çaşnigîr'in (709/1309-1310) tahta çıkmasını sağlamışlardır. Muhammed b. Kalavun'un üçüncü döneminde (709-741/13101341) sayılarının artması engellenebilse de ondan sonraki süreçte özellikle çocuk yaştaki sultanların tahta geçirilmesi ile emîrler arasında yaşanan mücadeleler idarî açıdan istikrarsızlığı getirmiştir. Bu durum, Çerkez memlüklerin yeniden güçlerini artırmasına yardımcı olmuştur. Nitekim Muhammed b. Kalavun sonrası süreçte idareye egemen olan nüfuzlu emîrlerden Yelboğa el-Ömerînin (öl. 768/1366) aralarında Berkuk'un da yer aldığı Çerkezlerden müteşekkil güçlü bir memlük grubu oluşturduğu görülmektedir. Böylece Berkuk'un önce emîrlik ardından tahta çıkmasıyla sonuçlanan süreç başlamıştır. ${ }^{1}$

\footnotetext{
Çerkezlerin iktidara gelme sürecine dair bk. M.C. Şehabeddin Tekindağ, Berkuk Devrinde Memlûk Sultanlığı (İs-
} tanbul: İstanbul Üniversitesi Edebiyat Fakültesi Yayınları 1961), 32-39. 
Emîrliği döneminde, mevkiini güçlendirerek rütbelerini artıran Berkuk, çok sayıda Çerkez memlük satın alarak Yelboğa el-Ömerî gibi bir memlük grubu oluşturmuştur. Böylece nüfuzunu daha da artırarak Türk Memlüklerle mücadeleye girmiş ve onların hâkimiyetine önemli bir darbe vurmuştur. ${ }^{2}$ Çağdaşı tarihçilerden Makrîzî, Berkuk'un kudretli olduğu ve idareyi yönlendirdiği emîrliği döneminde kâdılkudâtlara birtakım baskılar uyguladığına dair örnekler sunmaktadır. ${ }^{3}$ Muhtemelen bu durum, Berkuk'un bazı kâdılkudâtlar tarafından sevilmemesine neden olmuştur. Berkuk'un kâdılkudâtlara yönelik tavrının ilerde ele alınacağı gibi sultanlığı döneminde devam ettiği ve bazı kâdılkudâtların mezâlim mahkemesinde yargılandı̆̆ı tespit edilmiştir.

Berkuk'un sultanlığı döneminde devlet teşkilatının mahiyetine ve zihin yapısına dair birtakım esaslı müdahaleler yapıldığı görülmektedir. Bunlar arasında sultana ait memlüklerin maaşlarının ödenmesi ve her türlü ihtiyacının giderilmesi amacıyla ihdas edilen Dîvânü'l-müfred, ilk akla gelenlerdendir. Devletin idarî ve malî yapısının yeniden düzenlenmesine matuf olarak bu divanın kurulması ve başına üstâdârın getirilmesiyle iki önemli müessesenin ehemmiyetinin oldukça azaldığı anlaşılmaktadır. Bunlardan birincisi, Muhammed b. Kalavun döneminde ihdas edilen ve görevi sultana ait emlâk ve mallarla ilgilenmek olan hâs nâzırlığıdır. ${ }^{4}$ Diğeri ise devletin mâlî sisteminin tepesinde yer alan vezâret makamıdır. Berkuk'un bu iki divanî görevi tek çatı altında toplaması ve üstâdâra tâbî kılması, üstâdârlı̆̆ın önemini fevkalade artırmıştır. ${ }^{5}$

Berkuk döneminde dikkat çeken bir diğer husus, Muhammed b. Kalavun'dan kırk yıl sonra mezâlim mahkemesini yeniden canlandırılmasıdır. Böylece kâdılkudâtların ve halkın gözüne girmek amacıyla önemli bir adım atıldı̆̆ı gibi, hem ulemânın hem de askerî sınıfın kontrol edilebilmesinin de önü açılmış olmalıdır. Zira Berkuk, özellikle emîrlerin isyanıyla mücadele etmek ve bir emîrin isyanı dolayısıyla tahttan bir süre çekilmek zorunda kalmıştır. ${ }^{6}$

Hz. Peygamber döneminde de uygulamaları görülen mezâlim mahkemeleri, İslam devlet başkanlarının halka temas ettiği hususî bir alandır. Mezâlim mahkemeleri, Ortaçağ İslam dünyasında hak ihlallerinin, halkın şikâyetlerinin ve devlet ricâli arasındaki ihtilafların görüşüldüğü, hükümdarın başkanlığını yaptığı en yüksek yargı kurumudur. Abbâsîler döneminde (132-656/750-1258) tam olarak müesseseleştiği görülen mezâlim mahkemeleri için müstakil binalar da yaptırılmıştır. Yine bu dönemde Mısır'da ilk defa

2 Berkuk'un emîrliği dönemindeki faaliyetler için bk. Tekindă̆, Berkuk Devrinde Memlûk Sultanlı̆̆ , 44-52.

3 Makrîzî, es-Sülûk li-ma'rifeti düveli'l-mülûk, nşr. Muhammed Abdülkâdir ‘Atâ (Beyrut: Dâru'l-Kütübi'l-İlmiyye, 1997), 5/57, 92-93, 124, 136.

4 Hâs nâzırlı̆̆ı ile ilgili geniş bilgi için bk. Şihâbüddîn el-Kalkaşendî, Șubhu'l-aş̧â fî șinấati'l-inşâ (Kahire: elMatba 'atü'l-Emîriyyeti, 1914), 4/30, 11/316-320, 339; Donald P. Little, "Notes on the Early Nazar al-Khass", The Mamluks in Egyptian Politics and Society, ed. Thomas Philips - Ulrich Haarmann (Cambridge: Cambridge University Press, 1998), 240-242.

5 Dîvânü'l-müfred'in görev sahası, önemi, hâs nâzırlığı ile ilişkisi ve ne zaman kurulduğuna dair geniş bilgi için bk. Fatih Yahya Ayaz, “Çerkez Memlükler Döneminde Üstâdârlık (Saray Ağalığı)”, Çukurova Üniversitesi Sosyal Bilimler Enstitüsü Dergisi, 22/1 (2013), 304-310.

6 Berkuk dönemi iç ve dış siyasî gelişmeler için bk. Tekindağ, Berkuk Devrinde Memlûk Sultanlığı, 55-83; İsmail Yiğit, Memlükler (648-923/1250-1517) (İstanbul: Kayıhan Yayınevi, 1991), 99-105. 
mezâlim mahkemesine başkanlık eden Tolunoğulları (254-292/868-905) hanedanı kurucusu Ahmed b. Tolun (254-270/868-884) olmuştur. Tolunoğulları'ndan sonra Mısır'da mezâlim geleneği, İhşî̂liler (323-358/935-969) ve Fâtımîler (297-567/909-1171) döneminde de devam etmiştir. Memlüklerin (648-923/1250-1517) selefi Eyyûbîlerin (567866/1171-1462) kurucusu Selâhaddin Eyyûbî (567-589/1171-1193), Nûreddin Mahmûd Zengînnin (541-569/1146-1174) Şam ve Halep'te mezâlim oturumlarının gerçekleşmesi için yaptırdığı dârüladli örnek alarak Kahire'de de inşa ettirmiş ve burada mezâlim oturumlarını yönetmiştir. Böylece, Eyyûbîler döneminde de mezâlim geleneği varlığını sürdürmüş̧ür. ${ }^{7}$

Devlet teşkilatlanmasında Eyyûbî mirasını devralan Memlüklerde sultanlar, devletin kuruluşundan itibaren mezâlim oturumlarına önem vermişlerdi. Bununla birlikte seleflerinden farklı olarak zaman içerisinde mezâlim mahkemesine dair birtakım düzenlemeler yaptıkları görülmektedir. Nitekim devletin kuruluşundan Berkuk dönemine gelinceye kadar mezâlim mahkemesi, iki temel değişim geçirdi. Bunlardan birincisi, devletin asıl kurucusu sayılan el-Melikü'z-Zâhir Baybars (658-676/1260-1277) döneminde dört Sünnî fikıh mezhebinden birer kâdılkudât ataması yapılmasıydı. Böylece mezâlim mahkemesinin üye sayısı artırıldı ve daha önce sadece Şâfiî mezhebi temsil edilirken, yeni uygulama ile farklı mezheplerin görüşlerinden de mahkemede istifade edildi. Diğeri ise mezâlim oturumlarının gerçekleştirildiği mekana dair değişikliklerdir. Şöyle ki mezâlim mahkemesinin toplandığı ilk mekan, Memlüklerin ilk sultanı el-Melikü’l-Muiz İzzeddin Aybek (648-655/1250-1257) döneminde dârüladl binası yerine Sâlihiyye medresesiydi. ${ }^{8}$ Sultan Baybars döneminde mezâlim oturumlarının tertip edilmesi amacıyla dârüladl binası inşa edildi ve 662 (1264) yılından itibaren davalara burada bakıld1. ${ }^{9}$ Böylece, Baybars dönemiyle birlikte mezâlim davalarına müstakil bir yer tahsisi yapılmış oldu.

el-Melikü'l-Mansûr Kalavun (678-689/1279-1290) döneminde ise sultanların ikametgahı olarak kullanılan Kal'atülcebel'de ${ }^{10}$ "Eyvân" denilen bir salonda, mezâlim duruşmaları burada tertip edilmiştir. ${ }^{11}$ Burası Muhammed b. Kalavun döneminde yıkılarak "Eyvânü'l-Kebîr” adıyla yeniden inşa edilmiş ve Bahrî Memlüklerin sonuna kadar dârüladl

\footnotetext{
Memlükler dönemi öncesi mezâlim mahkemeleri hakkında genel bilgi için bk. Jorgen S. Nielsen, Secular Justice in an Islamic State: Mazalim Under The Bahri Mamluks 662/1264 - 789/1387 (Istanbul: Nederlands Historisch-Archaelo, 1985), 1-15; a.mlf., "Mazālim”, The Encyclopaedia of Islam New Edition (Leiden: Brill, 1991) 6/933-935; Nasser O. Rabbat, "The Ideological Significance of the Dar al-Adl in the Medieval Islamic Orient", International Journal of Middle East Studies, 27/1 (1995), 3-28; Celal Yeniçeri, “Mezâlim” Türkiye Diyanet Vakfi İslâm Ansiklopedisi (İstanbul: TDV Yayınları, 2004), 29/515-518. Eyyûbîler döneminde mezâlim mahkemeleri için ayrıca bk. Ayşe Dudu Kuşçu, Eyyûbî Devleti Teşkilâtı (Ankara: Türk Tarih Kurumu, 2013), 376-379.

8 İsmail Hakkı Uzunçarşıl1, Osmanlı Devleti Teşkilatına Medhal (Ankara:Türk Tarih Kurumu, 1970), 373; Fatih Yahya Ayaz, Türk Memlükler Döneminde Saray Ağalı̆̆ -Üstâdarlı (1250-1382) (İstanbul: Marmara Üniversitesi İlahiyat Fakültesi Vakfı (IFAV) Yayınları, 2008), 36.

9 Nielsen, Secular Justice in an Islamic State, 51.

10 Başkent Kahire'deki Mukattam dağı yakınlarında bulunan ve Eyyûbîler döneminde yaptırılan bu saray hakkında bk. Kalkaşendî, Șubhu'l-a'şâ, 3/372-379; Eymen Fuâd Seyyid, "Kahire”, Türkiye Diyanet Vakfi İslâm Ansiklopedisi (İstanbul: TDV Yayınları, 2001), 24/174.

11 Takıyyüddîn Makrîzî, el-Mevâiz ve el-ítibâr bi Zikr el-Hitat ve el-Âsâr, nşr. Muhammed Zeynuhum - Medîha eşŞerkâvî (Kâhire: Mektebe Medbûlâ; 1998), 3/48; Nielsen, Secular Justice in an Islamic State, 51.
} 
olarak kullanılmıştır. Bununla birlikte Muhammed b. Kalavun'dan itibaren Berkuk dönemine kadarki sultanlar, mezâlim oturumlarına yeteri kadar önem vermemişlerdir. ${ }^{12}$

Bahrî Memlükler dönemde (648-784/1250-1382) mezâlim oturumlarının resmî toplantı günleri, pazartesi ve perşembe olarak karşımıza çıkmaktadır. ${ }^{13}$ Araştırmacı Nielsen, söz konusu dönemde elli dokuz davanın mezâlim oturumlarında karara bağlandığını tespit etmiştir. Onun tespitine göre bu davalar, askeriye ve ilmiye sınıfı mensuplarının görevlerini kötüye kullanmalarıyla ilgili şikâyetler, müsâdere, vakıf malları ve mukaddesâta hakaret gibi meselelerle ilgilidir. ${ }^{14}$

Bahrî Memlükler döneminde mezâlim mahkemesinin yargılama usulüne dair araştırmacılardan Nielsen ve Şeker'in verdiği bilgiler, Berkuk döneminde bu usule bağlı kalınıp kalınmadığına dair test imkanı sunması bakımından oldukça faydalıdır. Bununla birlikte kaynaklarda Berkuk döneminde yeni bir yargılama usulü getirildiğine dair doğrudan herhangi bir bilgi bulunmamaktadır. Bahsi geçen araştırmacıların aktardığına göre, genellikle yazılı olarak yapılan müracaatların dilekçeleri inşâ divanında toplanird. Bazen de doğrudan sultana ya da önde gelen bir emîre şifahi olarak şikayetler iletilirdi. Sultana okunan bu dilekçelere zaman zaman sultan doğrudan kendisi hüküm verir, bazen ilgili görevliye hüküm vermesi için sevk ettirir, bazılarını da mezâlim mahkemesinin resmî toplantı günlerinde görüşülmesini emrederdi. Davanın konusuna göre ilgili görevliye sevk edilen dilekçe için verilen hüküm sultanın onayı ile yürürlüğe girerdi. Yine mahkemenin resmî toplantı günlerinde görüşülen davalarda alınan kararlar üzerinde sultanın önemli etkisinin olduğu anlaşılmaktadır. Mahkeme heyeti, sanık veya müsstekîden iddialarının doğru olduğuna dair yemin etmelerini, şahit veya delil getirmelerini isteyebilmektedir. Bazı durumlarda mahkeme ertelenerek suçlamaların veya savunmaların doğruluğu araştırılmaktadır. Mahkemede hüküm verilmeden önce müzakere yapıldığı ve mahkeme üyesi emîrlerin bazı davaların sonucunu etkileyebilecek müdahalelerde bulunabilmektedir. Verilen hükmün ivedilikle uygulanmasına dikkat edilmektedir. ${ }^{15}$

Mezâlim mahkemesi heyetini oluşturanların genel bir listesini veren Nielsen, daha sonra bunlar arasında önemli gördüğü hâcib, sır kâtibi, dârüladl müftüsü ve devâdâr hakkında bilgi vermiştir. Şeker ise mahkemenin aslî görevlileri ve yardımcı görevliler şeklinde bir ayrıma giderek daha detaylı bir liste hazırlamış ve bu görevliler hakkında bilgi vermiştir. ${ }^{16}$ Bununla birlikte bahsi geçen görevlilerin hepsinin aynı anda oturumlarda yer almadığını, bir kısmının zaman zaman ihtiyaç duyulduğunda mahkemede hazır bulunduğunu belirtmiştir. ${ }^{17}$ Kaynaklarda, Sultan Berkuk'un mahkeme üyelerinde değişikliğe gittiğine dair bir kayda rastlanmaz. Bununla birlikte yukarıda değinildiği gibi kurumlara yaptığı birtakım müdahaleler dolayısıyla önemi artan üstâdârın mezâlimde etkinliğinin artması muhtemeldir.

\footnotetext{
2 Nielsen, Secular Justice in an Islamic State, 51.

13 Mehmet Şeker, Memlûklerde Dîvânü'l-Mezâlim (1250-1517) (İstanbul: Ötüken Neşriyat, 2020), 223-227.

14 Nielsen, Secular Justice in an Islamic State, 144-156.

15 Nielsen, Secular Justice in an Islamic State, 63-77; Şeker, Memlûklerde Dîvânü'l-Mezâlim, 250-256.

16 Nielsen, Secular Justice in an Islamic State, 79-92.

17 Şeker, Memlûklerde Dîvânü'l-Mezâlim, 166-222.
} 
Bu makale, Burcî Memlükler (784-923/1382-1517) döneminin ilk hükümdarı Berkuk ile sınırlandırılmıştır. Çünkü Berkuk, emîrliğinden itibaren öne çıkması, Memlükler döneminin önemli sultanları arasında yer alması ve mezâlim oturumlarına özen göstermesiyle ilgi uyandırmaktadır. Nitekim Sultan Berkuk dönemi tarihçilerinden İbn Dokmak (öl. 809/1407), 794 (1391-1392) yılı olaylarını ele alırken Sultanın mezâlim mahkemesinde adaletle hükmettiğini, burada halkın taleplerinin karşılık bulduğunu ve zayıfın hakkını alabildiğini naklederek bu konuya işaret etmektedir. ${ }^{18}$

Berkuk döneminin ele alınmasının bir başka sebebi, Berkuk'un mezâlim mahkemesinin mekânına ve zamanına dair birtakım düzenlemeler de yapmıs olmasıdır. Tespitimize göre bu düzenlemelere ilk işaret eden araştırmacı, Bahrî Memlükler döneminde mezâlim mahkemesini ele aldığı çalışmasında Jorgen Nielsen olmuştur. Onun aktardığına göre Berkuk, mezâlim oturumlarına yeni bir bina tahsis ederek burada halka açık bazı törenleri de icra etmiştir. ${ }^{19}$ Daha sonra Nasser Rabbat, Ortaçağ İslam dünyasında dârüladlin önemini ele aldığı makalesinde bu meseleye temas ederek, Berkuk'un bu düzenlemesi ile Kalavun geleneğine son verdiğini ve saltanatı yeniden yapılandırdığını savunmuştur. ${ }^{20}$ Onun bu reformuna Linda Darling ve Albrecht Fuess de işaret etmiş ancak bu dönemdeki davalara dair herhangi bir incelemede bulunmamışlardır. ${ }^{21}$ Bununla birlikte Fuess'in mezâlim oturumlarına dair değerlendirmesi oldukça kıymetlidir. Ona göre, bu oturumlar Memlük sultanlarına âdil bir yönetici olma fırsatı kazandırdığı gibi saray çevresini kontrol altına almaya da yardım etmiş ve bu yüzden güçlü Memlük sultanları mezâlim oturumlarına önem vermiştir. ${ }^{22}$ Onun bu değerlendirmesi, Burcî Memlükler dönemini tesis eden ve Memlükler döneminin güçlü sultanları arasında yer alan Berkuk'a olan ilgimizi daha da artırmıştır.

Japon araştırmacı Fumihiko Hasebe ise Berkuk döneminde mezâlime gelen şikâyetlerin sosyo-politik analizini yaptığı bir makale ele almıştır. ${ }^{23}$ Berkuk'un, mezâlim oturumları vesilesiyle halkla iyi bir iletişim kurma imkânı bulduğuna ve devletin, mazlumun yanında olduğunu gösterme çabası içinde olduğuna dair tespiti oldukça önemlidir. ${ }^{24}$ Ancak bu tespiti yaparken, ilerde ele alınacağı gibi bazı tarihçilerin mezâlim davalarının görüşüldüğü mekânda yapılan değişikliğe dair eleştirilerine temas etmemiştir. Hasebe, bu makalesinde Berkuk döneminde on sekiz mezâlim davası tespit etmiştir. Bizim tespitimize göre ise dava sayısı yirmi ikidir. Ondan farklı olarak 4, 10, 15 ve 20 no.lu davalar tespit edilmiştir. Yine onun bazı konularda istifade etmediği birtakım Memlük kaynaklarını da

18 İbn Dokmak, el-Cevherü's-șemîn fi siyeri'l-hulefâ ve'l-mülûk ve's-selâțin, nşr. Muhammed Kemâleddin İzzeddin Ali (Beyrut: Âlemü'l-Kütüb, 1985), 284.

19 Nielsen, Secular Justice in an Islamic State, 51-52.

20 Nasser O. Rabbat, "The Ideological Significance of the Dar al-Adl”, 18.

21 Linda T. Darling, "Medieval Egyptian Society and the Concept of the Circle of Justice," Mamlūk Studies Review 10/2 (2006), 14; Albrecht Fuess, "Žulm by Mažālim? The Political Implications of the Use of Mažālim Jurisdiction by the Mamluk Sultans”, Mamlūk Studies Review, 8 (2009), 126.

22 Albrecht Fuess, “Zulm by Maz̄ālim?”, 130.

23 Fumihiko Hasebe, "Sultan Barqūq and his Complaining Subjects in the Royal Stables", Al-Masāq 21/3 (2009), 315-330.

24 Hasebe, "Sultan Barqūq", 325-326. 
kullanarak rivayet farklılıklarını ortaya koyma firsatı yakalanmıştır. Örneğin 5 no.lu davanın tarihine dair onun başvurmadığı tarihçilerden İbn Tağrîberdî ve Abdülbâsit el-Malatî̉nin nakillerinden bu davanın tam tarihine ulaşılmıştır. Bir başka örnek, el-Istablü’sSultânî'deki ${ }^{25}$ ilk davanın tarihi meselesidir. O, bu konuda sadece İbnü'l-Furât'in görüşünü nakletmiş ve ilk toplantının gününe işaret etmemiştir. Bu konuda ondan farklı olarak Makrîzî, Aynî, İbn Kâdî şühbe, Sehâvî, Abdülbâsıt el-Malatî ve Hatîb el-Cevherî gibi tarihçilere de başvurularak, görüş farklllığına işaret edilmiştir. Hasebe, Berkuk döneminde mezâlim davalarının zamanının iki kez değiştiğini aktarırken, ${ }^{26}$ bu değişikliğin üç kez olduğu tespit edilmiştir. Bir diğer farklılık, onun mezâlim davalarında halk tabakasının konumunu ortaya koymasına karşılık, bu makalede aleyhine mezâlim davası açllan ilmiye ve askeriye mensupları tespit edilerek davaların daha çok hangi sınıfa yönelik olduğu incelenmiştir.

Ülkemizde Berkuk döneminde mezâlim mahkemesine dair müstakil bir çalışma bulunmamaktadır. Ancak Berkuk dönemiyle ilgili önemli tespitlere yer veren Şehabeddin Tekindă̆, adlî teşkilata dair birtakım hususlara temas etmiş, bununla birlikte Berkuk'un mezâlim davalarına yer vermemiştii. ${ }^{27} \mathrm{O}$, Berkuk döneminde mezâlim oturumlarının zamansal değişimine işaret etmiş ancak mekânsal değişimden bahsetmemiştir. ${ }^{28}$ Yine Memlükler döneminde mezâlim mahkemesini inceleyen Mehmet Şeker, müesseseyi, işleyişini ve teşkilat yapısını ortaya koymuş, Berkuk döneminde mezâlim oturumlarının yeni binasına ve vakitlerine dair önemli bilgiler aktarmıştır. Ancak davalara dair birkaç örnek vermekle yetinmiştir. ${ }^{29}$

\section{Mahkemenin Mekanına ve Zamanına Dair Değişiklikler}

Sultan Berkuk'un 784 (1382) yılında tahta çıktığında önceden olduğu gibi mezâlim oturumlarının düzenlendiği mekâna dair geleneği sürdürdüğü görülmektedir. Nitekim o, Muhammed b. Kalavun tarafindan yaptırılan ve Kal'atülcebel'de bulunan dârüladl binasında 789 (1387) yılına kadar beş yll boyunca mezâlim oturumlarına başkanlık yaptı 789 (1387) yılında ise el-Istablü's-Sultânî'de söz konusu davalara ilk kez bakmaya başladı. Berkuk döneminin sonuna kadar, mezâlim davalarına burada bakıldı. ${ }^{30}$ Buradaki ilk oturumun ne zaman yapıldığına dair tarihçiler, Ramazan (Ekim) ayında olduğu konusunda ittifak etmelerine rağmen ayın kaçıncı günü olduğuyla ilgili ihtilaf içindedirler.

Nitekim Berkuk'un çağdaşlarından İbnü'l-Furât (öl. 807/1405), 23 Ramazan (7 Ekim) Pazartesi ${ }^{31}$ Makrîzî (öl. 845/1442) 28 Ramazan (12 Ekim) Pazar, ${ }^{32}$ Aynî (öl. 855/1451) Makrîzî

25 Sultana ait ahır anlamına gelen el-Istablü's-Sultânî, Memlükler döneminde sultana ait binek hayvanların bulunduğu ahırlardır. Bu ahırlar, sultanların ikametgâhı olan Kal'atülcebel içerisinde yer almaktaydı. bk. Abdülkadir Özcan, "Istabl" Türkiye Diyanet Vakfi İslâm Ansiklopedisi (İstanbul: TDV Yayınları, 1999), 19/203.

26 Hasebe, "Sultan Barqūq", 318-319.

27 Tekindă̆, Berkuk Devrinde Memlûk Sultanliğı, 147-149.

28 Tekindağ, Berkuk Devrinde Memlûk Sultanlı̆̆, 115.

29 Şeker, Memlûklerde Dîvânü'l-Mezâlim, 36, 223-227.

30 Makrîẑ̂, Hitat, 3/53; Hasebe, "Sultan Barqūq", 317; Şeker, Memlûklerde Dîvânü'l-Mezâlim, 236.

31 Nâsırüddîn İbnü'l-Furât, Târîhu ibni'l-Furât, nşr. Necla İzzeddin - Kostantin Züreyk (Beyrut: el-Matba atü'l-Emîr Kâniyye, 1936), 9(1)/17-18.

32 Makrîzî, Hitat, 3/53; a.mlf., es-Sülûk, 5/200. 
ile aynı tarihi nakletmekle birlikte cumartesi gününe işaret etmektedir. ${ }^{33}$ İbn Kâdî Şühbe (öl. 851/1448) ise Ramazan ayı içerisinde ilk oturumun gerçekleştiğini belirtmektedirler. ${ }^{34}$ Diğer tarihçilerden Sehâvî (öl. 902/1497) ve Abdülbâsıt el-Malatî (öl. 920/1514), İbn Kâdî Şühbe'yi destekleyerek ilk oturumun Ramazan ayı içerisinde yapıldığını bildirmektedirler. ${ }^{35}$ Bu meseleye temas eden tarihçilerden Hatîb el-Cevherî (öl. 900/1495) 18 Ramazan'da (2 Ekim) ${ }^{36}$ ve İbn İyâs (öl. 930/1524) 8 Ramazan (22 Eylül) Pazar ${ }^{37}$ Sultanın el-Istablü'sSultânî de davalara bakmaya başladığını nakletmektedirler. İbn Hacer (öl. 852/1449) ve İbn Tağrîberdî (öl. 874/1470) ise bu konuya yer vermemiştir. Modern araştırmacılardan Hasebe, diğer rivayetlere işaret etmeksizin İbnü'l-Furât'ın rivayetini aktarmakla yetinmektedir. ${ }^{38}$ Şeker ise sadece Makrîzînin rivayetine işaret etmektedir. ${ }^{39}$ Dolayısıyla Berkuk'un el-Istablü's-Sultânî'de ilk kez davaya baktığı tarihe dair beş farklı görüş tespit edilmiştir. Söz konusu dönemin tarihçileri arasında mevcut olan ihtilaf, son dönem Memlük tarihçileri arasında da devam etmiştir. Ayrıca yeni mekândaki ilk oturumun gününe dair de derin bir ihtilaf yaşandığı görülmektedir. Şöyle ki İbnü'l-Furât'ın pazartesi olarak aktardı̆̆ı tarih, Aynî’ye göre doğru olmakla birlikte Makrîzî̀ye göre salı olmalıdır. İbn İyâs'ın pazar olarak naklettiği tarih, İbnü'l-Furât ve Aynîye göre de pazar, Makrîzîye göre ise pazartesidir. Bu durum, el-Istablü's-Sultânî'deki ilk oturumun hangi günde yapıldı̆̆ının tespitini oldukça zorlaştırmaktadır.

Bu değişikliğin sebebine kaynaklar işaret etmemekle birlikte, bazı tarihçiler tarafından değişikliğin hoş karşılanmadığı izlenimi verilmekte ve bu değişiklik eleştirilmektedir. Nitekim İbn Hacer, âdî insanların ihanet etmesine kapı aralandığı için bu yeni durumun insanları rahatsız ettiği kanaatindedir. ${ }^{40}$ Hatîb el-Cevherî, tellâlların duyurduğu bu yeni değişikliğin, devlet ricâlini iftiralara mâruz bıraktığını belirtmektedir. ${ }^{41}$ Sehâvî, bu düzenlemeyle rezilliklerin hâkimiyet kurduğu düşüncesindedir. ${ }^{42}$ Abdülbâsıt el-Malatî ise yeni uygulamayla a'yânı korku sardığını ifade etmektedir. ${ }^{43}$ Genel itibariyle çağdaşı olmayan tarihçilerin aktardığı bu kayıtlardan, Berkuk'un halkın desteğini almak için yaptığı anla-

33 Bedreddin el-Aynî, 'ịkdü'l-cümân fî târîhi ehli'z-zamân (İstanbul: Beyazıt Devlet Kütüphanesi, Veliyyüddin Efendi, 2395), 225.

34 Takıyyüddîn İbn Kâdî Şühbe, Târîhu İbn Kadi Şühbe, nşr. Adnan Derviş (Dımaşk: Institut Français de Damas, 1997), 3/221.

35 Abdülbâsit el-Malatî, Neylü'l-emel fi zeyli'd-Düvel, nşr. Ömer Abdüsselâm Tedmürî (Beyrut: el-Mektebetü'l-Asriyye, 2002), 2/250; Şemseddin Sehâvî, Vecîü̉'l-kelâm fi'z-žeyl 'alâ Düveli'líslâm, nşr. Beşşâr Avvâd Ma'rûf - İsâm Fâris el-Harestânî - Ahmed el-Hutaymî (Beyrut: Müessesetü'r-Risâle 1995), 1/281.

36 Hatîb el-Cevherî, Nüzhetü'n-nüfûs ve'l-ebdân fi tevârîhi'z-zamân, nşr. Hasan Habeşî (Kahire: Dâru'l-Kütüb, 1970), $1 / 157$.

37 İbn İyâs, Bedâ’' ‘u'z-zühûr fì vekāa'i'i'd-dühûr, nşr. Muhammed Mustafa (Kahire: el-Hey'etü'l-Mısriyyetü'l-Amme li'l-Kitâb, 1982), 1(2)/388.

38 Hasebe, "Sultan Barqūq", 318.

39 Şeker, Memlûklerde Dîvânü'l-Mezâlim, 236.

40 İbn Hacer el-Askalânî, İnbâ'ü'l-ġumr bi-ebnâ’i'l-'umr, nşr. Hasan Habeşî (Kahire: Lecnetu İhyai't-Türasi'l-i̇slamî, 1969), $1 / 331$.

41 Hatîb el-Cevherî, Nüzhetü'n-nüfûs, 1/157.

42 Sehâvî, Vecîzül-kelâm, 1/281.

43 el-Malatî, Neylü'l-emel, 2/250. 
şllan düzenlemeyle devlet ricâlinin baskı altına alındığı hatta zaman zaman iftiralara uğradığı anlaşılmaktadır. Ancak tarihçiler, sadece 5 no.lu davada sanıklardan şafiî kâdılkudâtının suçsuz olduğu halde sultan tarafindan azledildiğine işaret etmişlerdir. 19 ve 21 no.lu davalarda görüldüğüu üzere sanık değil de müsstekînin cezalandırılması, mezâlim oturumlarının devlet ricâli üzerinde baskı oluşturmak amaçlı tertip edildiği şeklindeki genellemeyi çürütmektedir.

Berkuk, mekân değişikliği ile birlikte mezâlim oturumlarının günü konusunda da düzenlemeye gitmiş̦tir. Ondan önce mezâlim davalarına, pazartesi ve perşembe günleri bakılması âdet iken Sultan Berkuk, üç kez mezâlim oturumlarının zamanını değiştirmiştir. Bunlardan ilki, bu oturumların pazar ve çarşamba günleri gerçekleşeceğine dair değişikliktir. Kaynaklar, bu değişikliğin kesin tarihini aktarmamakla birlikte, mezâlim oturumlarının dârüladlden el-Istablü's-Sultânî̀ye nakledilmesiyle başladığı izlenimi oluşturmaktadırlar. ${ }^{44}$ Ancak, mezâlim oturumlarının el-Istablü’s-Sultânîye taşınmadan önce görülen 5 no.lu davanın pazar günü gerçekleştirilmiş olması, bu izlenimin doğru olmadığını ortaya koymaktadır. Daha önce geçtiği gibi el-Istablü's-Sultânî'deki ilk oturumun gününe dair tarihçiler arasındaki ihtilaf, Berkuk'un mezâlim oturumlarının resmî toplantı günü olarak bilinen pazartesi ve perșembe günlerinde de muhtemelen kısa bir süre davalara bakmış olabileceğini akla getirmektedir.

Yaklaşık sekiz yıl boyunca pazar ve çarşamba günleri mezâlim oturumlarına başkanlık eden Sultan, 6 Şevval 797 (25 Temmuz 1395) Cumartesi gününden itibaren bunu salı ve cumartesi şeklinde değiştirmiştir. Bu değişikliğin sebebine dair bazı tarihçiler, Sultanın pazar ve çarşamba günlerini eğlenceye ve şarap içmeye ayırdığını göstermektedir. ${ }^{45}$

Makrîzî, mezâlim oturumlarının zamanına dair sebebine işaret etmeksizin üçüncü bir değişiklikten bahsetmekle birlikte bu değişikliğin hangi tarihte gerçekleştiğini kaydetmemektedir. Buna göre Sultan, salı ve cumartesi günlerine ek olarak cuma ikindi sonrası da mezâlim oturumlarına başkanlık etmiştir. ${ }^{46}$ Bu değişiklik, muhtemelen Berkuk döneminin sonuna doğru gerçekleştirilmiştir. Zira yine Makrîzî, Rebîulâhir 801 (Aralık 1398Ocak 1399) tarihinde Sultanın tellâllar göndererek âdet olduğu üzere salı ve cumartesi günü mezâlime bakıldığını duyurduğunu belirtmektedir. ${ }^{47}$ Muhtemelen bu tarihten sonra cuma günü ikindi sonrası da mezâlim oturumları gerçekleştirilmiş olmalıdır.

\section{Davalar}

Sultan Berkuk döneminde tespit edilen yirmi iki mezâlim davası, hakkındaki dava sayısı çoktan aza doğru olmak üzere üç başlık altında incelenmiştir. Kaynaklarda yer alan davalar, kronolojik sıraya riayet edilerek tablo halinde makalenin sonunda yer almaktadır. Her davaya bir numara verilmiş ve verilen numaralara atıf yapılarak konu ele alınmıştır.

${ }^{44}$ Makrîzî, Hitat, 3/53; ibn İyâs, Bedầi'u'z-zühûr, 1(2)/388.

45 İbnü'l-Furât, Târîhu İbni'l-Furât, 9(2)/412; Makrîzî, es-Sülûk, 5/286; i̇bn Hacer, İnbẩül'-ġumr, 1/396; Abdülbâsıt el-Malatî, Neylü'l-emel, 2/289.

46 Makrîzî, Hitat, 3/53.

${ }^{47}$ Makrîzî, es-Sülûk, 5/433. 


\section{1. İlmiye Sınıfi Mensupları Hakkındaki Davalar}

Berkuk döneminde ilmiye sınıfı mensupları aleyhine on mezâlim davası tespit edilmiştir. Bunlardan 2, 4 ve 5 no.lu davalar, mezâlim oturumlarının el-Istablü’sSultânîye taşınmadan öncesine aittir. Söz konusu on davadan 4 no.lu dava hariç hepsinin müştekîlerinden bahsedilmektedir. Bununla birlikte sadece 15 no.lu davanın müştekîsi olan Şeyhûniyye hankahı şeyhüşşuyûhu Şerefüddin Yakub b. Celaleddin et-Tübânî’nin ${ }^{48}$ (öl. 827/1424) adı açıkça zikredilmiştir. Diğer müştekîler 2 no.lu davada Demenhûr ${ }^{49}$ muktası, 5 no.lu davada bir kadın, 8 no.lu davada Fârisî bir tüccar, 10 no.lu davada bir tüccar, 14 no.lu davada halk, 17 no.lu davada bir Hıristiyan, 20 no.lu davada Kavsun hankahı sûfîlerinden bir grup ve 22 no.lu davada çok sayıda müştekî şeklinde zikredilmektedir. Dolayısıyla, gayrimüslim, tüccar, âlim, çiftçi ve sûfîlerin ilmiye sınıfı mensupları aleyhinde mezâlim mahkemesine başvurduğu görülmektedir.

Söz konusu bu on davada şikâyet edilenlerin biri hariç hepsinin adlî ve dinî görevlerden birinde vazifeli olduğu tespit edilmiştir. Bunlar 2 no.lu davada muhtesip olarak zikredilen Şihabeddin b. el-Cündî ed-Demenhûrî (öl. 793/1390-1391) ${ }^{50}, 4$ no.lu davada Dımaşk'ta dört fakih, 5 no.lu davada Dımaşk şâfî̀ kâdılkudâtı Bedreddin Muhammed b. Ebi'l-Bekậ̂ (öl. 803/1400), 8 no.lu davada Dımaşk Şâfiî kâdılkudâtı Şihâbeddin el-Kureşî (öl. 793/1391) $)^{52}, 10$ no.lu davada Siryakus hankahı şeyhüşşuyûhu Aslam b. Nizâmeddin el-Isfahânî́s3 (öl. 802/1399), 14 no.lu davada Dımaşk şâfiî kâdılkudâtı Şihâbeddin elBâûnî ${ }^{54}$ (öl. 816/1413), 15 no.lu davada Hanefî fakihi ve müderris Mustafa el-Kirmânî ${ }^{55}$ (öl. 809/1406), 17 no.lu davada Kahire Mâlikîkâdılkudât nâibi Muhammed b. Şihâbeddin Ahmed, 20 no.lu davada Kavsun hankahı şeyhüşşuyûhu Taceddin Muhammed b. elMeymûnî ve 22 no.lu davada İskenderiye Mâlikî kâdılkudâtı Tâceddin Ebubekir b. edDimâmînî'dir.

İlmiye mensuplarına yönelik suçlamalarla ilgili kaynaklar, beş davanınkini açıkça zikrederken, dördünde şikâyet ${ }^{56}$ ve birinde ağır suçlamalar ${ }^{57}$ şeklinde genel ifadeler kullanmaktadırlar. Bu beș davanın suçlamaları arasında devlet başkanının Kureyşli olması

48 Hayatı hakkında bk. Makrîzî, es-Sülûk, 7/104; İbn Tağrîberdî, en-Nücûmü'z-zâhire fì mülûki Mıṣr ve'l-Kâhire, nşr. Muhammed Hüseyin Şemseddin (Beyrut: Dâru'l-Kütübi'l-îlmiyye, 1992), 14/297.

49 İskenderiye yakınlarında bir belde olup hakkında bk. Yâkût el-Hamevî, Mu'cemü'l-büldân ve Mu'cemü'l-üdebâ (Beyrut: Dâru Sadır, 1977), 2/472.

50 Hayatı için bk. İbn Hacer, İnbâ'ü'l-g்umr, 1/422.

51 Hayatı için bk. Şemseddin Sehâvî, eḍ-Dav'ü'l-lâmi' li-ehli'l-ḳarni't-tâsi`(Beyrut: Dâru'l-Ĉ̂l, 1992), 10/160; Şemseddin İbn Tolun, Kudâtü Dımaşk, nşr. Selahaddin el-Müneccid (Dımaşk: Matbuatü'l-Mecmai'l-İlmiyyi'l-Arabî, 1956), 117-119.

52 Hayatı için bk. İbn Tağrîberdî, el-Menhelü’ṣ-șâfive'l-müstevfi ba'de'l-Vâfî,nşr. Muhammed Muhammed Emin (Kahire: el-Hey'etü'l-Misriyyeti'l-Âmme li'l-Kitâb, 1984), 2/45-48.

53 Hayatı için bk. İbn Hacer, İnbâ'ü'l-ġumr, 2/113; Abdülhay b. Ahmed İbnü'l-İmâd, Şezerâtü'z-zeheb fí ahbâri men zeheb, nşr. Mahmûd Arnaûd - Abdülkadir Arnaûd (Beyrut: Dâru İbn Kesîr, 1993), 9/28.

54 Hayatı için bk. İbn Tağrîberdî, en-Nücûmü'z-zâhire, 14/124.

55 Hayatı için bk. İbn Hacer, İnbâ'ü'l-ġumr, 2/375; Sehâvî, eḍ-Dav'ü'l-lâmic, 10/160.

$562,14,17$ ve 22 no.lu davalar.

5720 no.lu dava. 
gerektiğine dair söylemlerle fitne çıarmak, ${ }^{58}$ gasp $^{59}$ ve küfür içeren sözler ${ }^{60}$ yer almaktadir.

Kaynaklar, mezâlim mahkemesinde ilmiye mensuplarının yargılanma sürecine dair doğrudan bilgiler vermemektedir. Bununla birlikte yargılama usulüne dair birtakım ipuçları nakledilmektedir. Nitekim 2 no.lu davada emîrler, verilen cezanın iptal edilmesini sağlamışlardır. ${ }^{61}$ Yargılama esnasında suça iştirak edenlerin ortaya çıkarılmasına da çalışılmıştır. Nitekim 4 no.lu davada devlet başkanının Kureyşli olması gerektiğine dair söylemlerle fitne çıkaran Dımaşk'taki dört fakih yargılanırken hangi emîrlerle işbirliği yaptıklarını itiraf edene kadar cezalandırılacakları bildirilmiş ve itiraf edene kadar cezalandırılmaları için Kahire valisine teslim edilerek hapse atılmışlardır. ${ }^{62}$ Abdülbâsıt el-Malatî, verilen cezanın işe yaradığını ve dört şahsın itirafta bulunarak Dımaşk nâibi Baydemir'in ${ }^{63}$ (öl. 789/1387) tutuklandığını bildirmektedir. ${ }^{64}$

Bazı durumlarda şikâyetin tahkikâtının yapıldı̆̆ı, sanığın ve verdiği isimlerin sorgulanması neticesinde rapor hazırlandığı görülmektedir. Nitekim 5 no.lu davada Sultan, büyük bir servet sahibi olan İsmail b. Mâzin'in (öl. 789/1387-1388) ${ }^{65}$ mirasında payı olduğunu ancak bunun başka bir mirasçı tarafından gasp edildiğini iddia eden kadının şikâyetinin doğruluğunun araştırılmasını emretmişti. ìlgili mirasçı, iddiaları reddederek terekenin Emînü'l-Hükm Muhibbiddin'de muhafaza edildiğini ileri sürdü. Bunun üzerine Sultan, Emînü'l-Hükm'ü ve Mısır Şâfiî kâdılkudâtı Bedreddin Muhammed b. Ebi'l-Bekâîyi huzuruna çağırdı. Emînü'l-Hükm, mirasçıyı yalanlayınca Sultan, murisin kırbaçlanmasını istedi. Muris kırbaçlanmaya başlayınca Emînü'l-Hükm'ün ve kâdılkudâtın terekeden haksız yere para aldığını söyledi. Tarihçi İbnü'l-Furât, bu söylentinin insanlar arasında da yayıldığını bildirmektedir. Bunun üzerine Sultan, Emînü'l-Hükm'ün de kırbaçlanmasını istedi. ${ }^{66}$ Şâfiî kâdılkudât ise terekeden pay almadığına dair üç talakla boş olma şartıyla yemin etti. Sultanın emriyle, Şâfiî kâdılkudâtın evinde İbn Mâzin'in murisi ve Emînü'lHükm, üstâdârü'l-âliye Seyfeddin Bahâdır ${ }^{67}$ (öl. 790/1388) gözetiminde yeniden sorgulandı. Buradaki sorgulama esnasında muris, darb edilmenin şiddetinden onlara iftira attığını kabul etti. Bunun üzerine emîr Bahâdır, şühûdu çağırarak murisin müfteri olduğuna ve Emînü'l-Hükm ile Şâfiî kâdıkudâtın terekeden pay almadıklarına dair rapor yazdırdı.

\footnotetext{
584 no.lu dava.

595 , 8 ve 10 no.lu davalar.

6015 no.lu dava.

61 İbn Hacer, İnbẩül-g̈umr, $1 / 318$.

62 Makrîzî,es-Sülûk, 5/191.

63 Hayatı için bk. İbn Kâdî Şühbe, Târîhu İbn Kadi Şühbe, 3/226-227; İbn Hacer, İnbâ'ül-g̈umr, 1/339-340; a.mlf., edDürerü'l-kâmine fi a ayâni'l-mi'eti's-sâmine (Beyrut: Dâru'l-Cîl, 1993), 1/513-514; İbn Tağrîberdî, el-Menhelü'ṣ-ṣâfi, 3/498-499; Abdülbâsit el-Malatî, Neylü'l-emel, 2/248.

64 Abdülbâsit el-Malatî, Neylü'l-emel, 2/243-244.

65 Hayatı için bk. İbn Hacer, İnbâ'ü'l-g̈umr, 1/339; İbn Tağrîberdî, en-Nücûmü'z-zâhire, 11/312; a.mlf., el-Menhelü’ṣșâfi, 2/420.

66 İbnü'l-Furât, Târîhu İbni'l-Furât, 9(1)/11.

67 Hayatı hakkında bk. İbn Tağrîberdî, el-Menhelü'ṣ-șâfi, 3/435. Üstâdârü'l-âliye hakkında bk. Ayaz, “Çerkez Memlükler Döneminde Üstâdârlı", 302-303.
} 
İbnü'l-Furât bu olay sonunda Sultanın Şâfiî kâdılkudâtı azledeceğine dair bir şayia yayıldığını nakletmektedir. ${ }^{68}$ İbn Hacer ise, bu olay dolayısıyla Berkuk'un Şâfiî kâdılkudâtı görevinden azlettiğini belirtmektedir. ${ }^{69}$ Abdülbâsit el-Malatî ise onun azil sebepleri arasında ona beslenen kin olduğunu söylemektedir. ${ }^{70}$ Dolayısıyla hazırlanan raporda Şâfiî kâdılkudâtın suçsuz olduğu ortaya konulmuş olsa da Sultanla ilişkilerinin bozulmuş olmasının etkisiyle bu olayın da etkisiyle Sultan onu azletmiştir.

Mahkeme heyetinin müştekînin delil sunmasını istediği ve bu delilleri inceleyerek karara vardığı görülmektedir. Bu hususun en açık örneği 8 no.lu davadır. Burada Dımaşk Şâfiî kâdılkudâtının mallarını gasp ettiğini iddia eden bir tüccar, mahkemenin talebi üzerine delillerini sunmuş ve mahkeme bu delilleri kabul ederek kâdılkudâtı mahkûm etmiştir. $^{71}$

Sultanın bir âlim hakkında olumsuz kanaate sahip olmasına rağmen doğrudan cezalandırmadığı, âlimin mahkemeye şikâyet edilmesini ve yargılanması neticesinde ceza almasını beklediği görülmektedir. Bunun en belirgin örneği 10 no.lu davadır. Bu davada bir tâcir, Siryakus Hankahı şeyhüşşuyûhu Aslam b. Nizâmeddin el-Isfahânîye çok sayıda kumaş emanet ettiğini ancak onları geri alamadığını ileri sürmüştü. Bunun üzerine Sultan, şeyhüşşuyûhun getirilmesi için bir mersûm çıartmıştı. Suçlamayı duyan şeyhüşşuyûh, Berkuk'un huzurunda özür beyan etmişti. Ancak mahkeme heyetinden birileri, Berkuk'a sihir yapmak için şeyhüşşuyûhun elinde yazılı bir şeyler bulunduğunu söylemişlerdi. Bunun üzerine Sultan, onun görevinden azledilmesine ve hem tâcirin hem de kendisinin emaneti alınana kadar şâddü'd-devâvîne ${ }^{72}$ teslim edilmesine karar vermişti. Tarihçiler bu olayı aktarırken, Sultanın şeyhüşşuyûha dair menfi kanaat sahibi olmasının nedenine de işaret etmektedir. Buna göre Emîr Yelboğa en-Nâsırînnin ${ }^{73}$ (öl. 793/1391) isyanının bastırılamaması ve isyancıların Kahire'ye doğru ilerlemesi üzerine Sultan Berkuk, kaçmak zorunda kalmıştı. Bu sırada Şeyhüşşuyûh Aslam'a kendisini saklaması karşılığında beş bin dinar vermiş ancak şeyhüşşuyûh, parayı almasına rağmen sözünde durmamıştı. Berkuk, ikinci kez tahta çıkınca, devâdârı göndererek şeyhüşşuyûhtan beş bin dinarını geri vermesini talep etmişti. Ancak şeyhüşşuyûh, parayı fakir fukaraya tasadduk ettiğini söylemişti. Bu cevap karşısında oldukça sinirlendiği aktarılan Sultan, tarihçilerin ifade ettiği üzere âdeti olduğu gibi sabretmeyi tercih etmiş ve bu sabrı, bir tâcirin şeyhüşşuyûhu şikâyet etmesiyle sonuç vermişti. ${ }^{74}$

İlmî ve dinî bir konuda mahkeme üyeleri arasında konunun tartışıldığı ve sanığın ilmiye sınıfına mensup olmasına rağmen emîrlerin kararlar üzerinde etkili olduğu görülmektedir. Nitekim 15 no.lu davada bir Hanefî fakihi, kitabında yer alan "Bir kişi, güneşe

\footnotetext{
68 İbnü'l-Furât, Târîhu İbni'l-Furât, 9(1)/14-15.

69 İbn Hacer, İnbâ'ü'l-g̈umr, 1/331.

70 Abdülbâsit el-Malatî, Neylü'l-emel, 2/250.

1 İbnü'l-Furât, Târîhu İbni'l-Furât, 9(2)/253; Makrîzî, es-Sülûk, 5/305; Hatîb el-Cevherî, Nüzhetü’n-nüfûs, 1/326.

72 Askerî görevliler arasında olan ve vezirin yardımcıları arasında zikredilen bu görevlinin mal müsaderelerinden sorumlu olduğu belirtilmektedir. Bk. Fatih Yahya Ayaz, Memlükler Döneminde Vezirlik (1250-1517) (İstanbul: Türkiye Diyanet Vakfı Yayınları, 2009), 223-225.

73 Hayatı için bk. İbn Hacer, İnbâ'ü’l-g̈umr, 1/431; a.mlf., ed-Dürerü'l-kâmine, 4/441-442.

74 Makrîzî, es-Sülûk, 5/325-326; Hatîb el-Cevherî, Nüzhetü'n-nüfûs, 1/347-348.
} 
ve aya karşı idrarını yapamaz. Çünkü bu ikisi, Allah dışında tapılan şeylerdir. Öyle ki Allah, Hz. İbrahim'in bunlara ibadete yönelmesini engellemedi." şeklindeki ifadeleri küfür içerdiği iddiasıyla suçlanmış, Mısır Mâlikî kâdılkudâtı Nâsıruddin Muhammed et-Tenesî ${ }^{75}$ (öl. 801/1399) onun katlini istemiş ancak bazı emîrler buna itiraz etmişlerdi. Bunun üzerine Sultan, Mısır Hanefî kâdılkudâtı Cemaleddin Mahmud elAcemînnin $^{76}$ (öl. 799/1396) hüküm vermesini emretmiş ve Hanefî kâdılkudât da ona sözlü tazir cezası vererek onu hapse atmıştı. Üç gün sonra da dövdürdükten sonra serbest birakmıştı. ${ }^{77}$

Mezâlimde yargılanan ilmiye mensuplarının tamamına ceza verildiği, cezalar arasında görevden el çektirme ${ }^{78}$, hapis ${ }^{79}$ ve dövdürmenin ${ }^{80}$ yaygın olduğu tespit edilmiştir. 2 no.lu dava örneğinde olduğu gibi Sultan, sanığın dövülmesi ve görevinden azledilmesi kararını verip uygulatmış, ancak muhtemelen mezâlim mahkemesinin üyeleri arasında bulunan emîrlerin araya girmesinden sonra verdiği karardan mahcubiyet duyarak mahkûmu affetmiş ve ona hilat giydirerek görevine iade etmiştir. ${ }^{81}$ İki davada ise sanığa iki farklı ceza verilmesine hükmedilmiştir. Bunlardan 8 no.lu davada sanık, önce kırbaçlanmış sonra hapse atılmıştır. ${ }^{82} 22$ no.lu davada ise önce görevinden azledilmiş ardından dövülmüştür. ${ }^{83} 15$ no.lu davada ise cezaların uygulanmasından sonra mahkûmun serbest bırakıldığı görülmektedir. Nitekim Hanefî fakihi Mustafa el-Kirmânînnin yazdığı bir kitapta küfür içeren ifadeler dolayısıyla yargılandıktan sonra genellikle ulemâ sınıfı için kullanılan azar ve tahkir şeklindeki sözlü tazir cezasına çarptırılarak hapse atılmıştır. Üç gün sonra ise dövülmüş ve serbest bırakılmıştır. ${ }^{84} 17$ no.lu dava örneğinde ise cezayı bizzat Sultanın uyguladığı zikredilmektedir. Onun, Mısır Mâlikî kâdılkudât nâibi Muhammed b. Şihâbeddin Ahmed'e yumruk atarak yere serdiği ve ardından da tekme attığı nakledilmektedir. Daha sonra da müştekî Hıristiyan'ın şikâyet ettiği şeyi alana kadar dövülmesini emrettiği bildirilmektedir. ${ }^{85}$

\section{2. Ümerâ Sınıfi Mensupları Hakkındaki Davalar}

Sultan Berkuk döneminde emîrler yani askerî sınıfa dair dokuz mezâlim davası tespit edilmiştir. Kaynaklara yansıyan bu davaların tamamı, mezâlim oturumlarının el-Istablü's-Sultânîye taşınması ve Berkuk'un ikinci kez tahta çıkması sonrasına aittir.

\footnotetext{
75 Hayatı için bk. İbn Hacer, Ref'u'l-isr 'an kudâti Mısr, nşr. Ali Muhammed Ömer (Kahire: Mektebetü'l-Hanci, 1998), 75-76; a.mlf., İnbầül'-ġumr, 2/63-64; İbnü'l-İmâd, Şezerâtü'z-zeheb, 9/15-16.

76 Hayatı için bk. İbn Hacer, İnbầül'-ġumr, 1/541-542; a.mlf., Ref'u'l-isr, 433; İbnü'l-İmâd, Şezerâtü’z-zeheb, 8/617.

77 İbnü'l-Furât, Târîhu íbni'l-Furât, 9(2)/401; Makrîzî, es-Sülûk, 5/368; İbn Hacer, İnbâ'ü'l-ğumr, 1/488; Hatîb el-Cevherî, Nüzhetü'n-nüfûs, 1/401.

7810,14 ve 20 no.lu davalar.

794 no.lu dava.

8017 no.lu dava.

81 İbn Hacer, İnbâü̈l'-gumr, 1/318.

82 İbnül'-Furât, Târîhu İbni'-Furât, 9(2)/253; Makrîzî, es-Sülûk, 5/305; Hatîb el-Cevherî, Nüzhetü’n-nüfûs, $1 / 326$.

83 Makrîzî̀, es-Sülûk, 5/412, 414.

84 Makrîzî, es-Sülûk, 5/368; Hatî̉ el-Cevherî, Nüzhetü’n-nüfûs, 1/401.

85 i̇bnü'l-Furât, Târîhu İbni'-Furât, 9(2)/402; Makrîzî, es-Sülûk, 5/369.
} 
Ümerâ hakkındaki dokuz davanın müştekîlerinin sadece ikisinin ismen zikredildiği görülmektedir. Bunlardan biri Hanefî fakihi Şihâbeddin Ahmed el-İbâdî̀ (öl. 801/1398), diğeri emîr Cemaleddin el-Hüzbânî̀ dir ${ }^{87}$ (öl. 802/1400). Kaynaklarda diğer müştekîler için ise "çok sayıda müştekî, Kerek halkı, çiftçiler, halk, bir grup Kûs halkı ve bir grup sûfî" şeklinde genel ifadeler kullanıldığı görülmektedir. ${ }^{88}$ Buradan hareketle emîrlerle ilgili şikâyetlerin çoğunlukla halka ait olduğu söylenmelidir.

Şikâyet edilenlerden sadece birinin Berkuk dönemi önde gelen emîrlerinden olduğu, diğerlerinin rütbesi tespit edilemeyen ikisi haricinde Kahire dışında düşük rütbeli görevlerde bulunduğu tespit edilmiştir. Bunlar el-Vechü'l-kıbelî saltanat nâibi Alaaddin Akboğa el-Mardînî ${ }^{89}$ (öl. 793/1390), Emîr Mülk, ${ }^{90}$ Kerek nâibi Hasan el-Küçkünị̂1 (öl. 801/1399), iki kez dava edilen Kâşifü'l-Cîze Emîr Nâsıruddin Muhammed b. Akboğa Âs ${ }^{92}$ (öl. 795/1393), Emîr Yelboğa ez-Zeynî, ${ }^{93}$ Kûs valisi Emîr Mengliboğa ez-Zeynî̀ ${ }^{94}$ ve iki kez dava edilen dönemin nüfuzlu emîrlerinden Saîdü’s-süedâ hankahı nâzırı Yelboğa es-Sâlimî'dir (öl. 811/1409). ${ }^{95}$ Dolayısıyla, Berkuk döneminde sarayda görevli olmayan emîrler hakkında daha yaygın olarak mezâlim davası açıldığı belirtilmelidir.

Kaynaklarda, ümerâya yönelik sadece üç suçlamadan bahsedilmektedir. Bunlardan 9 no.lu davada gasp, 13 no.lu davada eziyet, iftira ile gasp ve 19 no.lu davada vakıftan yararlanma hakkının haksız olarak sonlandırılması şeklindedir. Diğer davalarda ise açıkça bir suçlama belirtilmeksizin, genel bir ifade ile şikâyet edilmeleri üzere dava açıldı̆̆ı nakledilmektedir.

Emîrler aleyhindeki mezâlim davalarında yargılama sürecine dair kaynaklar herhangi bir nakilde bulunmaz. Bununla birlikte özellikle 9 no.lu davada dikkat çeken bir husus, müştekînin sanık Emîr Mülk'ün Dımaşk'taki bazı devlet ricâlinin onu kışkırtarak kendisini kırbaçlattığını iddia etmesine rağmen bu iddialara dair bir soruşturmadan bahsedilmemektedir. ${ }^{96}$ Bu örnekte de görüldüğü üzere ümerânın şikâyet edildiği mezâlim davalarıyla alakalı soruşturmaya ilişkin hususlarda kaynakların sessiz kalması, emîrlerin muhâkeme usulünün tespit edilememesine neden olmaktadır. Kaynakların bu konuda neden sustuğuna dair bir emâre bulunmamaktadır. Bununla birlikte 21 no.lu davada

\footnotetext{
8619 no.lu davanın müştekîsi olup hayatı için bk. İbn Hacer, İnbâ'ü̉l-ġumr, 2/58; İbn Tağrîberdî, en-Nücûmü’zzâhire, 13/6; İbnü'l-İmâd, Şezerâtü'z-zeheb, 9/13.

879 no.lu davanın müştekîsi olup hayatı için bk. Makrîzî, es-Sülûk, 6/36.

88 Dava numaraları sırasıyla şöyledir: 7,11,12,13, 14, 18 ve 19.

897 no.lu davanın sanığının hayatı için bk. İbn Hacer, İnbâ'ü’l-g̈umr, 2/69; İbn Tağrîberdî, el-Menhelü's-ṣâfi, 2/483484.

909 no.lu davanın sanığı olan emîr Mülk, emîr Tâz’ın (ö. 763/1362) kardeşi Cantemur'un (ö. 793/1390-1391) kız kardeşinin oğlu olup vefat tarihi tespit edilememiştir.

9111 no.lu davanın sanığı olup hayatı için bk. İbn Tağrîberdî, en-Nücûmü'z-zâhire, 12/261.

9212 ve 13 no.lu davanın sanığı olup hayatı için bk. Makrîzî, es-Sülûk, 5/343; İbn Tağrîberdî, en-Nücûmü'z-zâhire, 12/136-137.

9316 no.lu davanın sanı̆̆ı olup hayatı hakkında bilgi bulunamamıştır.

9418 no.lu davanın sanı̆̆ı olup hayatı hakkında bilgi bulunamamıştır.

9519 ve 21 no.lu davanın sanığı olup hayatı bk. İbn Hacer, İnbâ'ü'l-g̈umr, 2/417-418.

96 İbnü'l-Furât, Târîhu İbni'l-Furât, 9(2)/254; Makrîzî, es-Sülûk, 5/306; İbn Hacer, İnbâ'ü'l-g̈umr, 1/417; Hatîb el-Cevherî, Nüzhetü’n-nüfûs, $1 / 327$.
} 
görüldüğü üzere emîrler aleyhine bir dava devam ederken karşı bir dava açllabilmektedir. ${ }^{97}$

Yargılama neticesinde alınan kararlarda, emîrlerin görevlerinden azledilme, kırbaçlanma, dövülme yahut hapsedilme şeklinde cezaya çarptırıldığı görülmektedir. Nitekim 7 no.lu davada sanık dövülme, hapis ve azil, ${ }^{98} 9$ no.lu davada ise 200 kırbaç cezasına çarptırılmış ve muhtemelen kırbaç yaraları dolayısıyla üç gün sonra da ölmüştür. ${ }^{99} 12$ no.lu davada sanık, önce kırbaç sonra azil ${ }^{100} 13$ no.lu davada önce kırbaçlanma sonra mağdurların parasının kurtarılması için Kahire valisine teslim edilme şeklinde cezalandırılmışıı. ${ }^{101} 16$ no.lu davada azil ve kırbaçlanma sonrasında Müslümanların haklarını alması için Kahire valisine teslim edilme cezası verilmiştir. ${ }^{102} 18$ no.lu davada mağdur insanların haklarını kurtarması için Kahire valisine teslim edilmiş ve görevinden azledilmiştir. ${ }^{103} 21$ no.lu davada ise sanık yerine müştekî cezalandırılmıştır. Şöyle ki müştekînin müstehcen ve galiz ifadelerle suçlamasına karşılık, iddiaların asılsız olması dolayısıyla müş̧ekînin kırbaçlanıp hapse atılmasına karar verilmiştir. ${ }^{104}$ Dolayısılla mezâlime şikâyet edilen bazı emîrlerin, yargılama sonucunda suçsuz olduğu ortaya çıkarılarak, haklarında beraât kararı verilmiştir.

Ümerânın yargılandığı 11 no.lu dava ile 19 no.lu dava diğerlerine göre ilgi çekici olduğundan özellikle zikredilmelidir. 11 no.lu davada, mezâlim mahkemesinin isyan eden bir emîre tuzak kurmak amacıyla kullanıldığı görülmektedir. Nitekim 794 (1391-1392) y1lında Sis nâibi Tugaytemur'un (öl. 794/1392) isyan ettiğini öğrenen Sultan, bir plan yaparak Kerek halkının mezâlim mahkemesinde şehrin nâibinden şikâyetçi olmasını sağlayarak onu azledecek ve halkın talebiyle Tugaytemur onun yerine atanacaktı. Plan uygulanmış ve halkın talebi Tugaytemur'a iletilmişti. Bu duruma memnun olan Tugaytemur, Kerek nâibi olacağı düşüncesiyle Kahire'ye geldiğinde Sultan tarafindan önce hapse atılmış ${ }^{105}$ sonra da katledilmişti. ${ }^{106}$

19 no.lu dava ise vakıf nâzırlığına getirilen bir emîrin aleyhine açlan davanın beraât ile sonuçlanması bakımından dikkat çekicidir. Bu dava, 18 Cemâziyelâhir 797 (10 Nisan 1395) tarihinde Yelboğa es-Sâlimînnin Saîdü's-süedâ hankahı nâzırlı̆ı̆na atanması dolayısıyla hankahın işlerini vakıf şartlarına uygun olarak icra etmesiyle ilgiliydi. Vakıf şartlarının uygulanmasıyla vakıftan haksız yere yararlananlar hankahtan çıkarıldı. Bunun üzerine bir grup sûfî, onu Sultan Berkuk’a şikâyet etti. ${ }^{107}$ Dönemin tarihçilerinin aktardığı bil-

97 Makrîzî, es-Sülûk, 5/372-373; İbn Hacer, İnbâ'ü'l-ġumr, 1/492-493.

98 İbnü'l-Furât, Târîhu İbni'l-Furât, 9(2)/247.

99 İbnü'l-Furât, Târîhu İbni'l-Furât, 9(2)/254; Makrîzî, es-Sülûk, 5/306; İbn Hacer, İnbâ'ü'l-g̈umr, 1/417; Hatîb el-Cevherî, Nüzhetü'n-nüfûs, $1 / 327$.

100 İbnü'l-Furât, Târîhu İbni'l-Furât, 9(2)/335.

101 İbnü'l-Furât, Târîhu İbni'l-Furât, 9(2)/335; Makrîzî, es-Sülûk, 5/336.

102 İbnü'l-Furât, Târîhu İbni'l-Furât, 9(2)/402; Makrîzî, es-Sülûk, 5/369; İbn Hacer, İnbâ'ü'l-g̈umr, 1/491; Hatîb el-Cevherî, Nüzhetü'n-nüfûs, 1/402.

103 İbnü'l-Furât, Târîhu İbni'l-Furât, 9(2)/404-405; Makrîzî, es-Sülûk, 5/371.

104 Makrîzî, es-Sülûk, 5/410.

105 İbn Hacer, İnbầül-g̈umr, 1/436.

106 İbn Hacer, İnbâ'ü'l-g̈umr, 1/439.

107 Makrîzî, es-Sülûk, 5/371; Hatîb el-Cevherî, Nüzhetü’n-nüfûs, 1/406-407. 
giler, nâzırın haklı olduğunu ortaya koymaktadır. Nitekim Berkuk'un ilk yıllarında saltanat nâibi Sûdun eş-Şeyhûnînin ${ }^{108}$ (öl. 798/1396) bu hankahın nâzırlığını yürütürken sûfîlerin sayısının üç yüzden beş yüze çıkmasının yanı sıra son zamanlarda yağışların yetersizliği dolayısıyla Nil suyunun yeterince taşmamasının da vakıf gelirlerini olumsuz etkileyerek sûfillere her ay düzenli olarak verilen tatlı ve sabun ile yıllık verilen giyecek gibi temel ihtiyaçlardan kesintilerin başladı̆̆ı nakledilmektedir. Dolayısıyla vakıf gelirlerinin azalmasına rağmen sûfî sayısındaki artış, vakıftan yararlananları olumsuz etkiledi. Nâzır ise vakıf şartlarını uygulamak suretiyle vakıf gelirlerinden yararlanma hakkına sahip sûfîleri korumayı amaçlıyordu. Ancak kısa zamanda durumun daha da kötüleşmesi üzerine 1 Recep (22 Nisan) itibariyle hankahın mübaşirleri, mutfağı ve fırını kilitlemek zorunda kaldılar. Böylece sûfîlere günlük yemek ve ekmek de verilmez oldu. Bu durumu sûfîler, Sultan Berkuk'a şikâyet ettiler. Sultanın huzurunda kâdılkudâtların ve fakihlerin de yer aldı̆̆ı bir mezâlim meclisi akdedildi. Yapılan müzakereler sonucunda vakfiyenin araştırılmasına karar verildi. Bunun üzerine vakfiye, dört mezhep kâdılkudâtı ve sûfîlerin huzurunda hankahta okundu. Vâkıfın şartlarının uygulanması konusunda sûfî olarak hankahtan yararlanan Hanefî kâdılkudât nâibi Şihâbeddin Ahmed elİbâdî ve Şâfiî fakihi Zeyneddin Ebu Bekir el-Kumnî109 (öl. 833/1430) görevlendirildi. Ancak ikisi arasında husumet çıkınca kâdılkudâtlar, vakıf şartlarının uygulanmasına karar verdi ve toplantı sona erdi. Aynı gece, aralarında el-İbâdî ve el-Kumnî’nin de yer aldı̆̆ı elliye yakın sûfînin zengin olduğu ve vakıf şartlarını sağlamadığı gerekçesiyle vakıfla ilişkisi kesildi. Bunun üzerine onlar, özellikle hankah nâzırı hakkında tezvirata başladı. Ancak el-i̇bâdî bu konuda daha ileri giderek Yelboğa'nın kâfir olduğunu iddia etti. Yelboğa, bundan haberdar olunca durumu Berkuk'a iletti. Sultanın huzurundan ayrıldıktan sonra el-íbâdî ile karşılaştı ve onu elbisesinin yeninden tuttu. Bunun üzerine elİbâdî, Şâfiî mezhebinde bu hareketin istihfaf anlamına geldiğini ve bir âlimi küçümsemenin de kâfirlik alameti olduğunu belirtti. O sırada vezir Sa'deddin Nasrullah b. elBakarî $^{110}$ (öl. 799/1397), onları sakinleştirmek için Hicaziyye medresesine götürdü. Ancak el-i̇bâdî, Yelboğa'nın kâfir olduğu iddiasında ısrarcı olunca, durum Sultan Berkuk'a bildirildi. Meseleyi görüşmek üzere kâdılkudâtların da hazır bulunduğu bir oturum gerçekleştirildi. Sultanın huzurunda 8 Recep (29 Nisan) Perşembe günü düzenlenen oturumda Mısır Mâlikî kâdılkudâtı Nâsıruddin Muhammed et-Tenesî, el-i̇bâdî̀ye tazir cezası verilmesine hükmetti. Ancak tazir konusunda ihtilaf yaşandı. Sultan da Mısır Hanefî kâdılkudâtı Cemaleddin Mahmud el-Acemînnin hüküm vermesini istedi. O da elİbâdı̂nin başını açarak yürüttü ve hapse attı. 11 Recep (2 Mayıs) Cumartesi günü Hanefî kâdılkudâtın evine getirilen el-i̇bâdî, burada kırbaçlandı. Şâfiî fakihi Ömer b. Reslân elBulkînî (öl. 805/1403) kâdılkudâtlarla birlikte Yelboğa'nın evine giderek şefaatçi oldu ve el-i̇bâdînin serbest kalmasını sağladılar. ${ }^{111}$

\footnotetext{
108 Hayatı hakkında bk. İbn Hacer, İnbâ'ü'l-g̉umr, 1/517; İbn Tağrîberdî, el-Menhelü'ș-sâfî, 6/104-109.

109 Hayatı için bk. Makrîzî, es-Sülûk, 7/221; İbn Hacer, İnbâ'ü'l-gumr, 3/443; İbnü'l-İmâd, Şezerâtü'z-zeheb, 9/293.

${ }^{110}$ Hayatı için bk. İbnü'l-Furât, Târîhu İbni'l-Furât, 9(2)/478; Makrîzî, es-Sülûk, 5/405; İbn Hacer, İnbâ'ül-ġumr, 1/543; Abdülbâsıt el-Malatî, Neylü'l-emel, 2/379.

111 Makrîzî, es-Sülûk, 5/372-373; İbn Hacer, İnbâ'ü'l-g்umr, 1/492-493; Hatîb el-Cevherî, Nüzhetü'n-nüfûs, 1/407-410.
} 


\subsection{Mühtedilerle İlgili Davalar}

Mühtedilerle ilgili üç mezâlim davası tespit edilmiştir. Bunlardan ikisi Berkuk'un mezâlim davalarını el-Istablü's-Sultânî'ye taşımasından öncesine aittir. İlki, mühtedilerin camii görevlilerini darp etmesiyle ilgilidir. 1 no.lu bu dava, mezâlim mahkemesine Sultanın yanı sıra saltanat nâibinin de mahkemeye başkanlık yaptığını göstermesi bakımından önemlidir. Tarihçilerin aktardığına göre, Cemâziyelevvel 785'te (Temmuz 1383) Misır'ın kuzeyinde Garbiye'de Birma köyünde ${ }^{112}$ Hıristiyan asıllı mühtedilere ait çalgılı ve içkili bir düğün yapılmıştı. Gece yarısı âdet olduğu üzere müezzinin minareye çıkarak Allah'ı tespih etmesinden sonra düğüne katılanlar, onu minareden indirmiş ve ona yardıma gelen imam ve hatiple birlikte ölesiye dövmüşlerdi. Bazı Müslüman köylüler de olay yerine gelerek imam, hatip ve müezzini kurtarmaya çalışmışlardı. Olaydan sonra birkaç köylüyle beraber imam, hatip ve müezzin Kahire'ye gitmiş ve durumu saltanat nâibi Sûdun eş-Şeyhûnî̀ye aktararak şikâyetçi olmuşlardı. Saltanat nâibi, onları söz konusu köyün ikta sahibi olan emîr-i âhûr Çerkez el-Halîlî̀ye (öl. 791/1389) ${ }^{113}$ yönlendirdi. Onlar şikâyetlerini el-Halîlî̀ye aktarmalarına rağmen el-Halîlî, onlarla ilgilenmediği gibi anlatılanları da kabul etmedi. Ayrıca imam, hatip ve müezzini dövdürüp hapse attırdı. Köylüler ise öfkeyle, Ömer b. Reslân el-Bulkînî ile Mısır şâfiî kâdılkudâtı İbn Binti'l-Meylek'in ${ }^{114}$ (öl. 797/1395) yanına giderek olanları naklettiler. İbn Binti'l-Meylek, önce el-Halîlî’ye giderek hapistekilerin serbest bırakılmasını talep etti. Bu talebine olumlu yanıt aldıktan sonra birkaç köylüyle beraber Sultanın huzuruna çıkarak durumu ona ilettiler. Sultan, el-Halîlînnin yaptıklarını kabul edilemez buldu ve olayın araştırılması için Hâcib Aydegâr el-Ömerî̀yi ${ }^{115}$ (öl. 794/1391) görevlendirdi. Hâcib, Hıristiyan asıllı mühtedilerin haksızlıklarına dair hazırladığı raporu Berkuk'a iletti. Sultan da el-Halîlî ile birlikte onların yargılanmasını emretti. Mısır Mâlikî kâdılkudâtı Cemâleddin İbn Hayr ${ }^{116}$ (öl. 791/1389) onları hapse attırdı. 26 Cemâziyelâhir 785 (26 Ağustos 1383) Perşembe günü saltanat nâibi Sudûn başkanlığında Sâlihiyye medresesinde toplanan mahkemede Mâlikî kâdılkudât Birmalı altı kişinin mürted olduğuna hükmetti ve idamına karar verdi. ${ }^{117}$ Makrîzî, onların gusledildikten sonra kefenlendiklerini ve Müslüman mezarlığına defnedildiklerini bildirmektedir. ${ }^{118}$ Kaynaklar, Çerkes el-Halîlî̀ye verilen cezaya dair herhangi bir nakilde bulunmamakla birlikte aynı yılın Ramazan (EkimKasım) ayında Sultan tarafından affedildiğini bildirmektedirler. ${ }^{119}$

\footnotetext{
${ }^{112}$ Fusat'tan İskenderiye'ye doğru giderken Mısır'ın batısında kalan bir belde olan Burma hakkında bk. Yâkût elHamevî, Mu'cemü'l-büldân, 1/403.

${ }^{113}$ Hayatı için bk. Makrîzî, es-Sülûk, 5/270; İbn Hacer, İnbâü̈'l-güumr, 1/385.

${ }_{114}$ Hayatı için bk. İbn Hacer, İnbâü̈'l-g̈umr, 1/503; a.mlf., ed-Dürerü̈l-kâmine, 3/494-495.

${ }^{115}$ Hayatı için bk. İbn Tağrîberdî, el-Menhelü'ș-șâfi, III 157-158.

${ }^{116}$ Hayatı için bk. Makrîzî, es-Sülûk, 5/271; İbn Hacer, İnbâ'ü̈l-g̈umr, 1/386; a.mlf., ed-Dürerül'-kâmine, 3/137; i̇bn Tağrîberdî, en-Nücûmü'z-zâhire, 11/386.

${ }^{117}$ Makrîzî, es-Sülûk, 5/150-151; İbn Hacer, İnbâ'ül'-g̈umr, 1/273-274; Hatîb el-Cevherî, Nüzhetü’n-nüfûs, 1/67-68; Abdülbâsit el-Malatî, Neylül'-emel, 2/203; ibn İyâs, Bedẩi'u'z-zühûr, 1/2 330-331.

${ }^{118}$ Makrîzî, es-Sülûk, 5/151.

119 İbn Hacer, İnbâ'ül'-ġumr, 1/277.
} 
İkincisi, 3 no.lu dava olup 13 Şaban 788 (9 Eylül 1386) Salı günü Sultanın huzurunda Müslüman olarak hâs nâzırlığ ${ }^{120}$ görevine getirilen Mihâil el-Eslemî (öl. 789/1387) aleyhinedir. ${ }^{121}$ Müslüman olduktan kısa bir süre sonra Muharrem 789'da (Ocak/Şubat 1387) İskenderiye nâzırlığına getirilen Mihâil, kısa zamanda hakkında çok sayıda şikâyet olunca 10 Rebîulâhir'de (30 Nisan) görevinden azledildi ve Şâddü'd-devâvîn Cemaleddin Mahmud onu hapse attı. ${ }^{122}$ Yargılama neticesinde İskenderiyeli pek çok kişinin onun zındık olduğuna şehadet etmesiyle ayın 13’ünde (3 Mayı) Cumartesi günü idam edildi. ${ }^{123}$ Burada sanık hakkındaki iddiaların yoğunluğu dolayısıyla muhtemelen tedbir amacıyla görevinden alınmış ve hapsedilmiş, yargılama sonunda zındık olduğuna karar verilerek ölüme mahkûm edilmiştir.

Mühtedilerle ilgili son dava, 6 no.lu dava olup, Hıristiyan asıllı Şeyhü'l-Arab İbn Seba'nın ${ }^{124}$ (öl. 792/1390) şeriata aykırı işler yaptığına dair şikâyetlerle ilgilidir. Dava Mısır Şâfiî kâdılkudâtına nakledildi, o da öldürülmesine hükmetti. Ancak bu hüküm uygulanmayarak 6 Recep 791'de (1 Temmuz 1389) Yelboğa en-Nâsırînnin başkanlığında kâdılkudâtların da katıldığı bir oturum tertip edildi. Mısır Mâlikî kâdılkudâtı İbn Haldûn, Yelboğa'nın dirayetli bir emîr olduğunu ve bu yüzden şahsın idamına yahut serbest birakılmasına dair hükmü vermesini talep etti. İbn Hacer, İbn Seba'nın daha önce de tutukland1ğına ve rüşvetle serbest kaldığına dair dedikoduların olduğunu aktararak İbn Haldûn'un tutumunun muhtemel arka planına dair açıklamada bulunmuştur. İbn Haldûn'un bu sözü üzerine Yelboğa, onun serbest bırakılmasına hükmetti ve kâdılkudâtlar da bu hükme itiraz etmedi. Ancak İbn Seba', serbest bırakıldıktan bir gün sonra hamamda öldürüldü. ${ }^{125}$

\section{Sonuç}

Eyyûbîlerin devlet teşkilatı geleneğini tevarüs eden Memlüklerde tarihçiliğin oldukça gelişmiş olması, her ne kadar mahkeme kayıtları elimizde olmasa da mezâlim davalarıyla ilgili çalışma imkânı sunmaktadır. Özellikle güçlü Memlük sultanları dönemlerinde mezâlime dair kayıtlarda artış olduğu gözlerden kaçmamaktadır. Bunun önde gelen örneklerinden biri de Bahrî Memlükler dönemini sona erdirerek Burcî Memlükler dönemini başlattı̆̆ kabul edilen Sultan Berkuk dönemidir.

Bazı kurumların yapısına dair önemli müdahalelerde bulunan Sultan Berkuk, selefleri gibi mezâlim oturumlarıyla yakından ilgilenmiş ve yaptığı iki düzenlemeyle de dikkat çekmiştir. Bu düzenlemelerden birincisi, mezâlim oturumlarının yapıldığı binanın değiştirilmesidir. 784 (1382) yılında tahta çıkan Berkuk, 789 (1387) yılına kadar Muhammed b. Kalavun döneminden beri kullanılan dârüladl binasında mezâlim oturumlarına başkanlık yapmış, ancak daha sonra el-Istablü’s-Sultânî'de söz konusu oturumlar tertip edilmeye

\footnotetext{
120 Yukarıda izah edildiği gibi, hâs nâzırlı̆̆ı divânî görevler arasında olup, Dîvânü'l-müfred'in tesis edilmesiyle önemi azalmıştır.

121 Hatîb el-Cevherî, Nüzhetü'n-nüfûs, 1/150.

122 İbnü'l-Furât, Târîhu İbni'-Furât, 9(1)/6; İbnü'l-İmâd, Şezerâtü'z-zeheb, 8/526.

${ }^{123}$ Makrîzî, es-Sülûk, 5/198; İbn Hacer, İnbâ'ü'l-ġumr, 1/334; Hatîb el-Cevherî, Nüzhetü’n-nüfûs, 1/152.

124 Hayatı için bk. İbn Hacer, İnbâ'ü'l-ġumr, 1/402-403.

125 İbn Hacer, İnbâ'ül-g்umr, 1/370-371.
} 
başlanmıştır. Kaynaklar, bu düzenlemenin neden yapıldığına dair bir bilgi aktarmamaktadır. Bununla birlikte yapılan düzenlemenin devlet ricâlini baskı altına aldığına dair değerlendirmelerde bulunmuşlardır. Mekânda yapılan bu değişim, halkın daha kolay bir şekilde şikâyetlerini mahkemeye ulaştırmasına vesile olmuştu. Bu durum göz önüne alındığında, söz konusu düzenlemeyle sultanın devlet ricâlini kontrol altında tutmak ve onlara tahakküm etmek arzusunda olduğu akla gelmektedir. Ancak özellikle saray çevresinde görevli üst düzey rütbeli emîrler hakkında sadece bir mezâlim davası tespit edilmiştir. 0 da yargılama neticesinde beraat etmiştir. Bu dönemde mezâlimde yargılanan emîrler, çoğunlukla Kahire dışındaki bölgelerde görevli ve düşük rütbeliydi. Bununla birlikte ilmiye sınıfında durum biraz farklıdır. Öncelikle, hakkında mezâlim davası açılan ilmiye sınıfı mensuplarının biri hariç hepsinin bir görevi mevcuttu. Bunların önemli kısmının da Dimaşk Şâfiî kâdılkudâtll̆ğı, Kahire Mâlikî kâdılkudât nâibliği, İskenderiye Mâlikî kâdılkudâtlığı, Siryakus hankahı şeyhüşşuyûhluğu ve Kavsun hankahı şeyhüşşuyûhluğu gibi adlî veya dinî üst düzey bir göreve sahip olduğu tespit edilmiştir. Yargılama sonucu onların görevlerinden azledildiği de göz önüne alındığında, mezâlim oturumlarını halka daha açık hale getiren mekân değişikliğinin ilmiye sınıfına yönelik bir hamle olduğuna dair bir kanaat ortaya çıkmaktadır. Ancak burada akla gelen bir diğer husus, üst düzey ümerâ sınıfının halkla arasında iyi ilişkiler geliştirmeyi başararak mezâlim oturumlarının mekânına dair yapılan değişiklikten daha az etkilenmiş olma ihtimalidir. Yine ilmiye sınıfı aleyhine açılan davalarda ümerâyla işbirliğinin olup olmadığının da araştırılması, askerî sınıfın bu şekilde kontrol altında tutulduğunu düşündürmektedir.

Berkuk'un mezâlim oturumlarına dair ikinci düzenlemesi oturum günlerinin değiştirilmesi olmuştur. Berkuk, on altı yılllk iktidarı boyunca oturumların günlerini üç kez değiştirmiştir. Kuruluşundan itibaren Memlüklerde mezâlim oturumlarının pazartesi ve perşembe günleri toplanması âdetti. Berkuk bunu pazar ve çarşamba günleri olarak değiştirmiştir. Bu ilk değişikliğin kesin tarihi bilinmemektedir. Daha sonra 797 (1395) yılından itibaren salı ve cumartesi günleri mahkeme toplanmıştır. Tarihçiler, Sultanın pazar ve çarşamba günlerini emîrlerle eğlenceye ayırması dolayısıyla böyle bir değişliğe gittiğini belirtmektedirler. Yani onlara göre, mezâlim oturumlarından bir gün sonra Sultan, emîrlerle eğlenmek için bu şekilde bir tasarrufta bulunmuştur. Ancak bu izahât, yeterince doyurucu görünmemektedir. Üçüncü değişiklik ise salı ve cumartesi günlerine ilave yapılmak suretiyle cuma günü öğleden sonra oturumların düzenlemesi şeklindedir. Bu değişiklik sultanın iktidarının son yılına rastlamaktadır. Muhtemelen Sultan, halkla olan ilişkisini daha da artırmak amacıyla mezâlim oturumlarını üç güne çıkarmış olmalıdır.

Berkuk döneminde tespit edilen yirmi iki davanın onu ilmiye, dokuzu askerî s1nıf mensupları aleyhinedir. Geriye kalan üç dava da Hıristiyan asıllı mühtedîler aleyhinedir. Kaynaklarda müştekîlerin ismi nadiren zikredilmektedir. Bunun yerine, bir grup çiftçi, sûfî bir grup, bir tâcir, bir kadın ve bir Hıristiyan gibi genel ifadeler kullanılmaktadır. Bu durum, müştekîlerin çoğunluğunun halk tabakasından olduğunu ve Berkuk döneminde mezâlim mahkemesinin halkla olan yakın iletişimini göstermesi bakımından önemlidir. 
Mahkemeye yapılan başvurularda suçlamaların genel olarak açıç̧a ifade edilmeden şikâyet olarak bahsedildiği görülmektedir. Bununla birlikte bazı başvurularda müştekîlerin, mallarının gasp edildiğine dair suçlamalar da yer almaktadır. Bir davada ise bir âlimin yazdığı kitapta tevhide aykırı ifadelerin yer aldığına dair suçlama bulunmaktadır. Mühtedîlerle ilgili suçlamalar ise onların mürtedlik alametleri gösterdiklerine dairdir.

Mezâlim mahkemesinin yargilama usulüne dair doğrudan bir bilgi bulunmamaktadır. Ancak verilen bilgiler bir araya getirildiğinde genel bir çerçeve çizmek mümkündür. Çizilen bu çerçevenin Bahrî Memlükler döneminde söz konusu mahkemenin yargılama usulünden farklı olmadığını söylemek gerekmektedir. Öncelikle yapılan başvurunun ardından şikâyetin içeriğinin araştırıldığı görülmektedir. Mahkemeye getirilen sanığın söz hakkı bulunduğu ve savunmasının tahkik edildiği dikkat çekmektedir. İddiaların, delillerin ve muhtemel verilecek cezaların sultanın başkanlığında ilmiye ve askerî sınıfa mensup mahkeme üyeleri arasında tartışıldığı, bazı davalarda görüldüğü gibi ümerânın kararlar üzerinde doğrudan etkili olduğu, bununla birlikte asıl belirleyici olanın sultan olduğu tespit edilmiştir. Burada dikkat çeken husus, sultanın olumsuz ilişkiler geliştirdiği bazı şahısları doğrudan görevden almak yerine, bir şikâyet üzerine mezâlimde yargılama neticesinde azlettiğidir. Bu durum, özellikle ilmiye mensuplarında görülmektedir. Yargılama neticesinde kırbaçlanma, hapis, idam ve gasp edilen malların kurtarılması gibi verilen kararları uygulamak üzere sanık, askerî görevlilerden Kahire valisi veya şâddü'd-devâvîn'e teslim edilmektedir. Cezaları uygulayanların genellikle Kahire valisi ve şâddü'd-devâvîn olarak zikredilmesi Bahrî Memlükler döneminden farklı olarak karşımıza çıkmaktadır. Yargılamanın süresine dair açık kayıtlar bulunmamakla birlikte birtakım davalarda aynı gün karar alındı̆̆ı, bazılarının ise birkaç gün sürdüğü saptanmıştır.

\section{Ek}

Tablo 1: Sultan Berkuk Dönemi Mezâlim Davaları

\begin{tabular}{|c|c|c|c|c|}
\hline $\begin{array}{l}\text { Dava } \\
\text { No }\end{array}$ & Tarih & Konu & Karar & Kaynaklar \\
\hline 1 & $\begin{array}{l}785 \text { Cemâzi- } \\
\text { yelevvel } \\
\text { (Temmuz } \\
\text { 1383) }\end{array}$ & $\begin{array}{l}\text { Hiristiyan asıllı müh- } \\
\text { tedi bir grup köylü- } \\
\text { nün imam, hatip ve } \\
\text { müezzini darp etme- } \\
\text { leri. }\end{array}$ & $\begin{array}{l}\text { Hiristiyan asıllı köylü } \\
\text { grubun mürted oldu- } \\
\text { guna ve idam edilme- } \\
\text { sine karar verildi. }\end{array}$ & $\begin{array}{l}\text { Makrîzî, es-Sülûk, } \\
\text { 5/150-151; İbn Hacer, } \\
\text { İnbâ'ü'l-g̈umr, 1/273- } \\
\text { 274; Hatîb el-Cevherî, } \\
\text { Nüzhetü'n-nüfûs, } \\
\text { 1/67-68; Abdülbâsıt } \\
\text { el-Malatî, Neylül- } \\
\text { emel, 2/203; İbn İyâs, } \\
\text { Bedâ'i'u'z-zühûr, 1/2 } \\
\text { 330-331. }\end{array}$ \\
\hline 2 & $\begin{array}{l}788 \\
(1386 / 1387)\end{array}$ & $\begin{array}{l}\text { Demenhûr muktasi- } \\
\text { nın muhtesip Şeyh } \\
\text { Şihâbeddin b. el- } \\
\text { Cündî } \quad \text { ed-De- } \\
\text { menhûrîyi şikâyeti }\end{array}$ & $\begin{array}{l}\text { Şeyh Şihâbeddin döv- } \\
\text { dürüldü. Ancak bazı } \\
\text { emîrlerin araya gir- } \\
\text { mesiyle affedildi. }\end{array}$ & $\begin{array}{l}\text { İbn Hacer, İnbâ'ül- } \\
\text { gumr, } 1 / 318 .\end{array}$ \\
\hline
\end{tabular}




\begin{tabular}{|c|c|c|c|c|}
\hline 3 & $\begin{array}{l}10 \text { Rebîülâhir } \\
789 \text { (30 Nisan } \\
1387 \text { ) }\end{array}$ & $\begin{array}{l}\text { İskenderiye nâzırı } \\
\text { Mihâil el-Eslemî hak- } \\
\text { kında çok sayılda } \\
\text { şikâyet. }\end{array}$ & $\begin{array}{l}\text { Mihâil el-Eslemî, önce } \\
\text { görevinden azledildi } \\
\text { ve hapse atıldı. Daha } \\
\text { sonra zındık olduğuna } \\
\text { hükmedilerek idam } \\
\text { edilmesine karar ve- } \\
\text { rildi. }\end{array}$ & 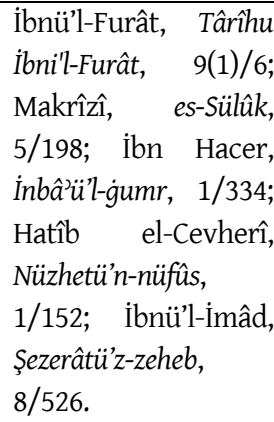 \\
\hline 4 & $\begin{array}{l}\text { Zilhicce } 788 \\
\text { (Aralık 1386- } \\
\text { Ocak 1387) }\end{array}$ & $\begin{array}{l}\text { Dımaşk'taki dört fa- } \\
\text { kihin devlet başkanı- } \\
\text { nın Kureyşli olması } \\
\text { gerektiğine dair söy- } \\
\text { lemleriyle fitne çı- } \\
\text { karması. }\end{array}$ & $\begin{array}{l}\text { Dört fakihe hapis ce- } \\
\text { zası verildi. }\end{array}$ & $\begin{array}{l}\text { Makrîzî, es-Sülûk, } \\
\text { 5/191; Abdülbâsit el- } \\
\text { Malatî, Neylül-emel, } \\
\text { 2/243-244. }\end{array}$ \\
\hline 5 & $\begin{array}{l}11 \text { Receb } 789 \\
(28 \text { Temmuz } \\
1387)\end{array}$ & $\begin{array}{l}\text { Payına düşen miras } \\
\text { hakkının gasp edildi- } \\
\text { ğine dair bir kadının } \\
\text { şikâyeti. }\end{array}$ & $\begin{array}{l}\text { Kadının miras hakkını } \\
\text { gasp edenin ve } \\
\text { Emînü'l-Hükm'ün kır- } \\
\text { baçlanmasına, Mısır } \\
\text { Şâfiî kâdılkudâtı Bed- } \\
\text { reddin Muhammed b. } \\
\text { Ebi'l-Bekâ̂̂nin göre- } \\
\text { vinden azledilmesine } \\
\text { karar verildi. }\end{array}$ & 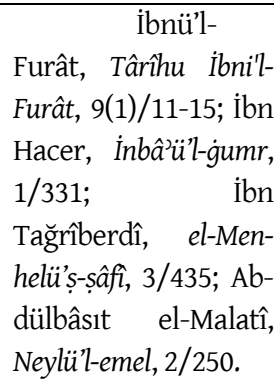 \\
\hline 6 & $\begin{array}{l}791 \\
(1388 / 1389)\end{array}$ & $\begin{array}{l}\text { Hristiyan asıllı } \\
\text { Şeyhü’l-Arab İbn } \\
\text { Seba'nın şeriata ay- } \\
\text { kırı işler yaptığına } \\
\text { dair şikâyet. }\end{array}$ & $\begin{array}{l}\text { Şeyhü'l-Arab İbn } \\
\text { Seba', suçsuz buluna- } \\
\text { rak serbest bırakıldı. }\end{array}$ & $\begin{array}{l}\text { İbn Hacer, } \\
\text { İnbâ'ü'l-ǵgumr, 1/370- } \\
371 .\end{array}$ \\
\hline 7 & $\begin{array}{l}15 \text { Safer } 793 \\
(22 \quad \text { Ocak } \\
1391)\end{array}$ & $\begin{array}{l}\text { Vechü’l-kıbelî salta- } \\
\text { nat nâibi Alaaddin } \\
\text { Akboğa el-Mardînî } \\
\text { hakkındaki çok sa- } \\
\text { yıda şikâyet. }\end{array}$ & $\begin{array}{l}\text { Alaaddin Akboğa el- } \\
\text { Mardînînin dövülme- } \\
\text { sine, azledilmesine ve } \\
\text { hapse atılmasına karar } \\
\text { verildi. }\end{array}$ & $\begin{array}{l}\text { İbnü'l-Furât, Târîhu } \\
\text { İbni'l-Furât, 9(2)/247. }\end{array}$ \\
\hline 8 & $\begin{array}{l}15 \text { Cemâzi- } \\
\text { yelâhir } 793 \\
(20 \quad \text { Mayıs } \\
\text { 1391) }\end{array}$ & $\begin{array}{l}\text { Fârisî bir tüccarın } \\
\text { mallarını gasp etti- } \\
\text { ğine dair Dımaşk Şâfiî } \\
\text { kâdılkudâtı Şihâbed- } \\
\text { din el-Kureşîyi } \\
\text { şikâyeti. }\end{array}$ & $\begin{array}{l}\text { Dımaşk Şâfiî kâdıl- } \\
\text { kudâtı Şihâbeddin el- } \\
\text { Kureşînin kırbaçlan- } \\
\text { masına ve hapse atıl- } \\
\text { masına karar verildi. }\end{array}$ & $\begin{array}{l}\text { İbnü'l-Furât, Târîhu } \\
\text { İbni'l-Furât, 9(2)/253; } \\
\text { Makrîzî, es-Sülûk, } \\
\text { 5/305; İbn Kâdî } \\
\text { Şühbe, Târîh, 3/372; } \\
\text { Hatîb el-Cevherî, } \\
\text { Nüzhetü'n-nüfûs, } \\
\text { 1/326. }\end{array}$ \\
\hline 9 & $\begin{array}{l}22 \text { Cemâzi- } \\
\text { yelâhir } 793\end{array}$ & $\begin{array}{l}\text { Emîr Cemâleddin el- } \\
\text { Hüzbânînnin Emîr } \\
\text { Mülk'ün haksız yere }\end{array}$ & $\begin{array}{l}\text { Emîr Mülk'ün kırbaç- } \\
\text { lanmasına karar ve- } \\
\text { rildi. }\end{array}$ & $\begin{array}{l}\text { İbnü'l-Furât, } \quad \text { Târîhu } \\
\text { İbni'l-Furât, } \\
\text { Makrîzî, } \\
\text { Mas)/254; }\end{array}$ \\
\hline
\end{tabular}




\begin{tabular}{|c|c|c|c|c|}
\hline & $\begin{array}{ll}(27 & \text { Mayıs } \\
1391) & \end{array}$ & $\begin{array}{l}\text { altı yüz bin dirhe- } \\
\text { mine el koyduğuna } \\
\text { ve kırbaçlattığına } \\
\text { dair şikâyeti. }\end{array}$ & & $\begin{array}{l}\text { 5/306; İbn Hacer, } \\
\text { İnbâü̈'l-gumr, } 1 / 417 \text {; } \\
\text { Hatîb el-Cevherî, } \\
\text { Nüzhetü'n-nüfûs, I } 327 .\end{array}$ \\
\hline 10 & $\begin{array}{l}15 \text { Şevval } 794 \\
\text { (4 Eylül 1392) }\end{array}$ & $\begin{array}{l}\text { Çok sayıda kumaş } \\
\text { emanet ettiği halde } \\
\text { geri alamadığına dair } \\
\text { bir tüccarın Siryakus } \\
\text { Hankahı şeyhüş- } \\
\text { şuyûhu Aslam b. } \\
\text { Nizâmeddin el-Is- } \\
\text { fahânîyi şikâyeti. }\end{array}$ & $\begin{array}{l}\text { Siryakus Hankahı şey- } \\
\text { hüşşuyûhu Aslam b. } \\
\text { Nizâmeddin el-Is- } \\
\text { fahânî, azledildi. }\end{array}$ & $\begin{array}{l}\text { Makrîzî, es-Sülûk, } \\
\text { 5/325-326; Hatîb el- } \\
\text { Cevherî, Nüzhetü’n- } \\
\text { nüfûs, 1/347-348. }\end{array}$ \\
\hline 11 & $\begin{array}{l}794 \\
(1391-1392)\end{array}$ & $\begin{array}{l}\text { İsyankâr Sis nâibi Tu- } \\
\text { gaytemur'un tuzağa } \\
\text { düşürülüp yakalan- } \\
\text { ması amacıyla Kerek } \\
\text { halkının nâiblerin- } \\
\text { den şikâyetçi olması. }\end{array}$ & $\begin{array}{l}\text { Tugaytemur'un yaka- } \\
\text { lanması amacıyla Ke- } \\
\text { rek nâibinin azledil- } \\
\text { mesi ve Kerek halkının } \\
\text { Tugaytemur'u nâibleri } \\
\text { olarak görmek isteme- } \\
\text { leri üzerine Tugayte- } \\
\text { mur'un Kahire'ye da- } \\
\text { vet edilmesine karar } \\
\text { verildi. }\end{array}$ & $\begin{array}{l}\text { İbn Hacer, İnbâ'üll- } \\
\text { ǵumr, 1/436. }\end{array}$ \\
\hline 12 & $\begin{array}{l}\text { Recep } 795 \\
\text { (May1s/Hazi- } \\
\text { ran 1393) }\end{array}$ & $\begin{array}{l}\text { Çiftçilerin Kâşifü'l- } \\
\text { Cîze Emîr Nâsıruddin } \\
\text { Muhammed b. Ak- } \\
\text { boğa Âs hakkındaki } \\
\text { şikâyeti. }\end{array}$ & $\begin{array}{l}\text { Kâşifü'l-Cîze } \quad \text { Emîr } \\
\text { Nâsıruddin Muham- } \\
\text { med b. Akboğa Âs'ın } \\
\text { azledilmesi. }\end{array}$ & $\begin{array}{l}\text { İbnü'l-Furât, Târîhu } \\
\text { İbni'-Furât, 9(2)/335. }\end{array}$ \\
\hline 13 & $\begin{array}{l}7 \text { Şaban } 795 \\
(18 \text { Haziran } \\
1393)\end{array}$ & $\begin{array}{l}\text { Emîr Nâsıruddin Mu- } \\
\text { hammed b. Akboğa } \\
\text { Âs'ın yeniden } \\
\text { Kâşifü'l-Cîze olarak } \\
\text { atanması üzerine } \\
\text { çiftçilerin kendile- } \\
\text { rine eziyet ettiğine, } \\
\text { evlatları konusunda } \\
\text { iftiralar attığına ve } \\
\text { mallarını gasp etti- } \\
\text { ğine dair şikâyeti. }\end{array}$ & $\begin{array}{l}\text { Emîr Nâsıruddin'in } \\
\text { kırbaçlanmasına ve } \\
\text { çiftçilerin parasını } \\
\text { ödemesine karar ve- } \\
\text { rildi. }\end{array}$ & 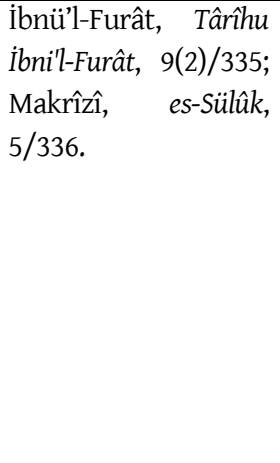 \\
\hline 14 & $\begin{array}{l}\text { Muharrem } \\
797 \\
\text { (Ekim/Kasım } \\
\text { 1394) }\end{array}$ & $\begin{array}{l}\text { Dımaşk Şâfiî kâdıl- } \\
\text { kudâtı Şihâbeddin el- } \\
\text { Bâûnî hakkında hal- } \\
\text { kın şikâyeti. }\end{array}$ & $\begin{array}{l}\text { Dimaşk Şâfiî kâdıl- } \\
\text { kudât Şihâbeddin el- } \\
\text { Bâûnı̂nnin görevinden } \\
\text { azledilmesi. }\end{array}$ & $\begin{array}{l}\text { İbn Hacer, İnbâ'ül- } \\
\text { ġumr, 1/486; Aynî, } \\
\text { 'ìkdü'l-cümân (Veliy- } \\
\text { yüddin Efendi, 2395), } \\
\text { 466. }\end{array}$ \\
\hline 15 & $\begin{array}{l}9 \text { Rebîülevvel } \\
797 \\
\text { (2 Ocak 1395) }\end{array}$ & $\begin{array}{l}\text { Hanefî fakihi Mustafa } \\
\text { el-Kirmânînnin yaz- } \\
\text { dığı bir kitapta, küfür } \\
\text { içeren ifadelerin yer }\end{array}$ & $\begin{array}{l}\text { Mustafa el-Kirmânî } \\
\text { hakkında sözlü tazir } \\
\text { cezası verilerek hapse } \\
\text { atıldı Üç gün sonra }\end{array}$ & $\begin{array}{l}\text { İ̉bnü'l- } \\
\text { Furât, Târîhu İbni'- } \\
\text { Furât, 9(2)/401; Mak- } \\
\text { rîzî, es-Sülûk, 5/368; }\end{array}$ \\
\hline
\end{tabular}




\begin{tabular}{|c|c|c|c|c|}
\hline & & $\begin{array}{l}\text { aldığına dair } \\
\text { Şeyhûniyye hankahı } \\
\text { şeyhüşşuyûhu Şere- } \\
\text { füddin Yakub b.Cela- } \\
\text { leddin et-Tübânı̂nnin } \\
\text { şikâyeti. }\end{array}$ & $\begin{array}{l}\text { hapisten çıarılarak } \\
\text { dövüldü ve serbest bı- } \\
\text { rakıldı. }\end{array}$ & $\begin{array}{l}\text { İbn Hacer, İnbâ'ü'l- } \\
\text { ġumr, } 1 / 488 \text {; Hatî̉b el- } \\
\text { Cevherî, Nüzhetü’n- } \\
\text { nüfûs, } 1 / 401 \text {. }\end{array}$ \\
\hline 16 & $\begin{array}{l}27 \text { Rebîülev- } \\
\text { vel } 797 \\
(20 \quad \text { Ocak } \\
1395)\end{array}$ & $\begin{array}{l}\text { Emîr Yelboğa ez- } \\
\text { Zeynî hakkında hal- } \\
\text { kın şikâyeti }\end{array}$ & $\begin{array}{l}\text { Emîr Yelboğa'nin gö- } \\
\text { revinden azledilme- } \\
\text { sine, kırbaçlanmasına } \\
\text { ve Müslümanların } \\
\text { haklarının alınması } \\
\text { için Kahire valisine } \\
\text { teslim edilmesine ka- } \\
\text { rar verildi. }\end{array}$ & $\begin{array}{l}\text { İbnü'l-Furât, Târîhu } \\
\text { İbni'l-Furât, 9(2)/402; } \\
\text { Makrîzî, es-Sülûk, } \\
\text { 5/369; İbn Hacer, } \\
\text { İnbẩü̈l-g̈umr, 1/491; } \\
\text { Hatîb el-Cevherî, } \\
\text { Nüzhetü'n-nüfûs, } \\
\text { 1/402. }\end{array}$ \\
\hline 17 & $\begin{array}{l}27 \text { Rebîülev- } \\
\text { vel } 797 \\
(20 \quad \text { Ocak } \\
1395)\end{array}$ & $\begin{array}{l}\text { Kahire Mâlikî kadıl- } \\
\text { kudat nâibi Muham- } \\
\text { med b. Şihâbeddin } \\
\text { Ahmet hakkında bir } \\
\text { Hıristiyanın şikâyeti. }\end{array}$ & $\begin{array}{l}\text { Kahire Mâlikî kadılku- } \\
\text { dat nâibi Muhammed } \\
\text { b. Şihâbeddin Ah- } \\
\text { met'in dövülmesine } \\
\text { karar verildi }\end{array}$ & $\begin{array}{l}\text { İbnü'l-Furât, } \quad \text { Târîhu } \\
\text { İbnil-Furât, } 9(2) / 402 ; \\
\text { Makrîzî, } \text { es-Sülûk, } \\
\text { 5/369; İbn Hacer, } \\
\text { İnbâ'ü'l-ġumr, 1/489. }\end{array}$ \\
\hline 18 & $\begin{array}{l}\text { 21 Cemâziye- } \\
\text { levvel } 797 \\
(14 \quad \text { Mart } \\
1395)\end{array}$ & $\begin{array}{l}\text { Bir grup Kûs halkının } \\
\text { Kûs valiliğine yeni- } \\
\text { den atanan Emîr } \\
\text { Mengliboğa ez- } \\
\text { Zeynîyi şikâyeti. }\end{array}$ & $\begin{array}{l}\text { Emîr Mengliboğa'nın } \\
\text { insanların haklarını } \\
\text { kurtarması için Kahire } \\
\text { valisine teslim edilme- } \\
\text { sine ve görevinden az- } \\
\text { ledilmesine karar ve- } \\
\text { rildi. }\end{array}$ & $\begin{array}{l}\text { İbnü'l-Furât, Târîhu } \\
\text { İbni'l-Furât, 9(2)/404- } \\
\text { 405; Makrîzî, es-Sülûk, } \\
\text { 5/371. }\end{array}$ \\
\hline 19 & $\begin{array}{l}18 \quad \text { Cemâzi- } \\
\text { yelâhir } 797 \\
(10 \quad \text { Nisan } \\
1395)\end{array}$ & $\begin{array}{l}\text { Saîdü’s-süedâ han- } \\
\text { kahı nâzırı Yelboğa } \\
\text { es-Sâlimînnin han- } \\
\text { kahtan çıardığı } \\
\text { sûfîlerin şikâyeti. }\end{array}$ & $\begin{array}{lr}\text { Vakfiyede } & \text { belirtilen } \\
\text { şartları } & \text { taşımayan } \\
\text { sûfillerin hankahtan } \\
\text { çıarılmasına karar } \\
\text { verildi. }\end{array}$ & $\begin{array}{l}\text { Makrîzî, es-Sülûk, } \\
\text { 5/372-373; İbn Hacer, } \\
\text { İnbâ'ü'l-g̈umr, 1/492- } \\
\text { 493; Hatîb el-Cevherî, } \\
\text { Nüzhetü'n-nüfûs, } \\
\text { 1/407-410. }\end{array}$ \\
\hline 20 & $\begin{array}{l}20 \text { Şevval } 799 \\
\text { (17 Temmuz } \\
\text { 1397) Aynîye } \\
\text { göre Zilkade } \\
\text { (Tem- } \\
\text { muz/Ağus- } \\
\text { tos) }\end{array}$ & $\begin{array}{l}\text { Kavsun hankahı } \\
\text { sûfîlerinden bir gru- } \\
\text { bun şeyhleri Taced- } \\
\text { din Muhammed b. el- } \\
\text { Meymûnîyi şikâyeti. }\end{array}$ & $\begin{array}{l}\text { Kavsun hankahı şeyhi } \\
\text { Taceddin Muhammed } \\
\text { b. el-Meymûnînin az- } \\
\text { ledilmesine karar ve- } \\
\text { rildi }\end{array}$ & $\begin{array}{l}\text { İbnü'l-Furât, Târîhu } \\
\text { İbni'l-Furât, 9(2)/467; } \\
\text { İbn Hacer, İnbâ'ü'l- } \\
\text { gumr, 1/529; Aynî, } \\
\text { cìkdü'l-cümân (Veliy- } \\
\text { yüddin Efendi, 2396), } \\
\text { 13. }\end{array}$ \\
\hline 21 & $\begin{array}{l}15 \text { Rebîülâhir } \\
800 \text { (5 Ocak } \\
1398)\end{array}$ & $\begin{array}{lr}\text { Hanefî } & \text { fakihi } \\
\text { Şihâbeddin } & \text { el- } \\
\text { İbâdî̀nin emîr } & \text { Yel- } \\
\text { boğa } & \text { es-Sâlimîyy } \\
\text { şikâyet etmesi. }\end{array}$ & $\begin{array}{l}\text { Müştekî Şihâbeddin } \\
\text { el-íbâdînin kırbaçla- } \\
\text { nıp hapse atılmasına } \\
\text { karar verildi. }\end{array}$ & $\begin{array}{l}\text { Makrîzî, } \quad \text { es-Sülûk, } \\
\text { 5/410. }\end{array}$ \\
\hline
\end{tabular}




\begin{tabular}{|c|c|c|c|c|c|}
\hline \multirow[t]{3}{*}{22} & 17 Şaban 800 & İskenderiye $\quad$ Mâlikî & Müsstekîler râzı olana & Makrîzî, & es-Sülûk, \\
\hline & Mayıs & kâdılkudâtı Tâceddin & kadar Tâceddin Ebu- & $5 / 414$ & \\
\hline & 1398) & $\begin{array}{l}\text { Ebubekir b. ed- } \\
\text { Dimâmînî hakkın- } \\
\text { daki șikâyetler. }\end{array}$ & $\begin{array}{l}\text { bekir b. ed- } \\
\text { Dimâmînînin } \\
\text { mesine karar verildi. }\end{array}$ & & \\
\hline
\end{tabular}

\section{Kaynakça}

Ayaz, Fatih Yahya. "Çerkez Memlükler Döneminde Üstâdârlık (Saray Ağalığı)”. Çukurova Üniversitesi Sosyal Bilimler Enstitüsü Dergisi 22/1 (2013), 291-322. https://doi.org/10.17335/sakaifd.219835

Ayaz, Fatih Yahya. Memlükler Döneminde Vezirlik (1250-1517). İstanbul:Türkiye Diyanet Vakfı Yayınları, 2009.

Ayaz, Fatih Yahya. Türk Memlükler Döneminde Saray Ağalğı -Üstâdarlk (1250-1382). İstanbul: İFAV Yayınları, 2008. https://doi.org/10.17335/sakaifd.219835

el-Aynî, Bedreddin. ‘'ikdü'l-cümân fî târîhi ehli'z-zamân. İstanbul: Beyazit Devlet Kütüphanesi, Veliyyüddin Efendi, 2395-2396.

Darling, Linda T.. "Medieval Egyptian Society and the Concept of the Circle of Justice". Mamlūk Studies Review 10/2 (2006), 1-17.

Fuess, Albrecht. “Žulm by Mažălim? The Political Implications of the Use of Mažālim Jurisdiction by the Mamluk Sultans". Mamlūk Studies Review 8 (2009), 121-147.

Hasebe, Fumihiko. "Sultan Barqūq and his Complaining Subjects in the Royal Stables". Al-Masāq 21/3 (2009), 315-330. https://doi.org/10.1080/09503110903343333

Hatîb el-Cevherî. Nüzhetü'n-nüfûs ve'l-ebdân fi tevârîhi'z-zamân. nşr. Hasan Habeşî. 4 Cilt. Kahire: Dârü'l-Kütüb, 1970-1994.

İbn Dokmak. el-Cevherü's-šemîn fí siyeri'l-hulefâ ve'l-mülûk ve's-selâțîn. nşr. Muhammed Kemâleddin İzzeddin Ali. Beyrut: Âlemü'l-Kütüb, 1985.

İbn Hacer el-Askalânî. ed-Dürerü'l-kâmine fi a'yâni'-mi'eti's-sâmine. 4 Cilt. Beyrut: Dâru'l-Cîl, 1993.

İbn Hacer el-Askalânî. İnbâ'ü'l-g̈umr bi-ebnẩi'l-umr. nşr. Hasan Habeşî. 4 Cilt. Kahire: Lecnetu İhyai'tTürasi'l-İslamî, 1969-1998.

İbn Hacer el-Askalânî. Ref'u'l-isr'an kudâti Mısr. nşr. Ali Muhammed Ömer. Kahire: Mektebetü'l-Hanci, 1998.

İbn İyâs. Bedẩi'u'z-zühûr fì vekā’i'i'd-dühûr. nşr. Muhammed Mustafa. 5 Cilt. Kahire: el-Hey'etü'l-Misriyyetü'l-Amme li'l-Kitâb, 1982-1984.

İbn Kâdî Şühbe. Târîhu İbn Kadi Şühbe. nşr. Adnan Derviş. 4 Cilt. Dımaşk: Institut Français de Damas, 1977-1997.

İbn Tağrîberdî. el-Menhelü'ș-șâfi ve'l-müstevfi ba'de'l-Vâfî. nşr. Muhammed Muhammed Emin. 13 Cilt. Kahire: el-Hey'etü'l-Mısriyyeti'l-Âmme li'l-Kitâb, 1984-2009.

İbn Tağrîberdî. en-Nücûmü'z-zâhire fî mülûki Mıṣr ve'l-Kâhire. nşr. Muhammed Hüseyin Şemseddin. 16 Cilt. Beyrut: Dârü'l-Kütübi'l-ìlmiyye, 1992.

İbn Tolun, Şemseddin. Kudâtü Dımașḳ. nşr. Selahaddin el-Müneccid. Dımaşk: Matbuatü'l-Mecmai'lİlmiyyi'l-Arabî, 1956.

İbnü'l-Furât, Nâsırüddîn. Târîhu İbni'l-Furat. nşr. Necla İzzeddin - Kostantin Züreyk. 9 Cilt. Beyrut: elMatba'atü'l-Emîr Kâniyye, 1936-1970.

İbnü'l-İmâd, Abdülhay b. Ahmed. Şezerâtü'z-zeheb fî ahbâri men zeheb. nşr. Mahmûd Arnaûd - Abdülkadir Arnaûd. 10 Cilt. Beyrut: Dâru İbn Kesîr. 1986-1993.

el-Kalkaşendî, Şihâbüddîn. Șubhuu'l-a'şâ fi șınấati'linşâ. 14 Cilt. Kahire: el-Matba'atü’l-Emîriyyeti, 1910-1920.

Kuşçu, Ayşe Dudu. Eyyûbî Devleti Teşkilâtı. Ankara: Türk Tarih Kurumu, 2013. 
Little, Donald P. "Notes on the Early Nazar al-Khass". The Mamluks in Egyptian Politics and Society. ed. Thomas Philips - Ulrich Haarmann. 235-253. Cambridge: Cambridge University Press, 1998. https://doi.org/10.3138/cjh.35.1.196

Makrîzî, Takıyyüddîn. el-Mevấiz ve el-i'tibâr bi Zikr el-Hitat ve el-Âsâr. nşr. Muhammed Zeynuhum Medîha eş-Şerkâvî. 4 Cilt. Kâhire: Mektebe Medbûlâ, 1998.

Makrîzî, Takıyyüddîn. es-Sülûk li-ma'rifeti düveli'l-mülûk. nşr. Muhammed Abdülkâdir 'Atâ. 8 Cilt. Beyrut: Dârü'l-Kütübi'l-İlmiyye, 1997.

el-Malatî, Abdülbâsit. Neylü'l-emel fi zeylid-Düvel. nşr. Ömer Abdüsselâm Tedmürî. 9 Cilt. Beyrut: elMektebetü'l-Asriyye, 2002.

Nielsen, Jorgen S.. "Mazālim”. The Encyclopaedia of Islam New Edition. 6/933-935. Leiden: Brill, 1991.

Nielsen, Jorgen S.. Secular Justice in an Islamic State: Mazalim Under The Bahri Mamluks 662/1264 - 789/1387. Istanbul: Nederlands Historisch-Archaelo, 1985. https://doi.org/10.2307/1571039

Özcan, Abdülkadir. "Istabl”. Türkiye Diyanet Vakfi İslâm Ansiklopedisi. İstanbul: TDV Yayınları, 1999, 19/203-206.

Rabbat, Nasser O.. "The Ideological Significance of the Dar al-Adl in the Medieval Islamic Orient". International Journal of Middle East Studies 27/1 (1995), 3-28. https://doi.org/10.1017/ s0020743800061559

Sehâvî, Şemseddin. eḍ-Dav'ü'llâmi' li-ehli'l-karni't-tâsi`. 12 Cilt. Beyrut: Dâru'l-Ĉ̂l, 1992.

Sehâvî, Şemseddin. Vecîzül'-kelâm fi'ż-zeyl 'alâ Düveli'l-İslâm. nşr. Beşşâr Avvâd Ma'rûf - İsâm Fâris elHarestânî - Ahmed el-Hutaymî. 4 Cilt. Beyrut: Müessesetü'r-Risâle 1995.

Seyyid, Eymen Fuâd. "Kahire”. Türkiye Diyanet Vakfi İslâm Ansiklopedisi. 24/173-175. İstanbul: TDV Yayınları, 2001.

Şeker, Mehmet. Memlûklerde Dîvânü'l-Mezâlim (1250-1517). İstanbul: Ötüken Neşriyat, 2020.

Uzunçarşıll, İsmail Hakkı. Osmanlı Devleti Teşkilatına Medhal. Ankara: Türk Tarih Kurumu, 2. Basım, 1970.

Yâkūt el-Hamevî. Mu'cemü'l-büldân ve Mu'cemü'l-üdebâ. 5 Cilt. Beyrut: Dâru Sadır, 1977.

Yeniçeri, Celal. "Mezâlim”. Türkiye Diyanet Vakfi İslâm Ansiklopedisi. 29/515-518. İstanbul: TDV Yayınlar1, 2004.

Yiğit, İsmail. Memlükler (648-923/1250-1517). İstanbul: Kayıhan Yayınevi, 1991. 